\title{
18. PELAGIC, TURBIDITIC, AND CONTOURITIC SEQUENTIAL DEPOSITS ON THE CAPE VERDE PLATEAU (LEG 108, SITE 659, NORTHWEST AFRICA): SEDIMENT RECORD DURING NEOGENE TIME${ }^{1}$
}

\author{
Jean Claude Faugères, ${ }^{2}$ Philippe Legigan, ${ }^{2}$ Noëlle Maillet, ${ }^{2}$ and Claude Latouche ${ }^{2}$
}

\begin{abstract}
On the Cape Verde Plateau, Neogene deposits are composed of major pelagic and hemipelagic sediments. These sediments show climatic sequences composed of two lithologic terms that differ in their siliciclastic and carbonate contents. Several turbiditic and contouritic sequences are interbedded in these deposits.

Turbidite sequences are fine grained and thin bedded with a very low frequency (about 12 sequences during the Neogene). They are composed of quartz-rich siliciclastic or volcaniclastic sediments. Quartz-rich turbidites originated from the Senegalese margin. Their slightly higher frequency during the early Pliocene indicates that the stronger turbidity currents, and probably the most abundant continental inputs, occur at that period. Volcaniclastic turbidites are only present in the early Miocene (about $17 \mathrm{Ma}$ ) and the early Pleistocene (1 Ma). They have flown from adjacent Cape Verde Islands and reflect two episodes of high volcanic activity in this area.

Contourite sequences, composed of biogenic sandy silts, represent less than $5 \%$ of the sediment pile and seem to have been mainly deposited during the late Pleistocene.

These different sequences show clay mineral variations throughout Neogene time. Kaolinite is predominant in the Miocene and lower Pliocene deposits; this mineral decreases thereafter, with an increased trend of illite in the uppermost Pliocene and Pleistocene sediments, suggesting a change in sediment sources on the Saharan continent at about 2.6 Ma.
\end{abstract}

\section{INTRODUCTION}

Site 659 is located on the uppermost part of the Cape Verde Plateau, which spreads between the Cape Verde Islands and the Senegal margin (Fig. 1). Three companion holes were cored continuously (659A and 659B) or spot cored (659C) in order to obtain a nearly complete stratigraphic sequence. On seismic records, Neogene sedimentation seems very regular; regularly distanced reflectors in a transparent layer overlie a stronger basal seismic layer. The Neogene sediment section recovered here (0-250 mbsf; Fig. 2) comprises two major lithologic units that have good biostratigraphic and magnetostratigraphic time control (Ruddiman, Sarnthein, et al., 1988).

Lower to upper Miocene sediments consist of pelagic cycles of light gray nannofossil ooze and yellowish brown or bluish nannofossil silty clay (Unit IIB; 24-7 Ma). We observed a sharp color change between the basal bluish ooze (Subunit IIB) and the overlying brownish ooze (Subunit IIA). Due to severe dissolution conditions, Unit II shows strong variations of carbonate contents. Upper Miocene to Holocene sediments (Unit I; 7-0 Ma) consist of pelagic cycles of white and light gray foraminifer-nannofossil ooze with minor amounts of silts and clays and with higher carbonate contents than in Unit II. The gradual change between the two units, with strong modifications in sedimentation rates and $\mathrm{CaCO}_{3}$ dissolution at 4.6 Ma, underlies a major event of deep-water oceanography. In addition, two events are recorded in Unit II: one is documented by the striking color change, about $11 \mathrm{Ma}$, the other by biostratigraphic evidences of an early Miocene hiatus spanning from around 18.5 to $23.5 \mathrm{Ma}$ (Ruddiman, Sarnthein, et al., 1988).

\footnotetext{
${ }^{1}$ Ruddiman, W., Sarnthein, M., et al., 1989. Proc. ODP, Sci. Results, 108: College Station, TX (Ocean Drilling Program).

2 Laboratoire de Géologie-Océanographie, Université de Bordeaux I, Avenue des Facultes, Talence 33405 Cedex, France.
}

Except for two major lithologic changes, pelagic and hemipelagic sediments appear very homogeneous throughout the two units. However, some levels composed of coarsegrained foraminifer ooze and a few dark centimetric layers of siliciclastic clayey-sandy silts are interbedded in the Neogene sediments. About 12 of these dark layers have been numbered in Holes 659A or 659B (Fig. 2); they are composed of major terrigenous or volcanic material.

Because of its geographic situation, the Cape Verde Plateau could be supplied with sediments originating from the Senegalese continental margin (quartz-rich, siliciclastic material) and from the Cape Verde Islands (volcanic material). Because of its morphologic situation, recent sediments will have major pelagic or hemipelagic characters (Diester-Haass, 1975; Moyes et al., 1979) and turbidite deposits should be rare. Nevertheless, these last deposits are common in Paleogene and Miocene sediments (Dean et al., 1978). Also, several works have reported that recent sediments were controlled by bottom currents (Hobart et al., 1975; Sarnthein et al., 1982; Lonsdale, 1982; Jacobi and Hayes, 1982; Meinert, 1985; Sarnthein and Meinert, 1986) related to the North Atlantic or to the Antarctic bottom water.

Microphysiographic studies show a lot of evidence such as sediment-wave fields. But these wave sediments are fine grained without typical contouritic features (Sarnthein and Meinert, 1986); and, consequently, contour current processes are not always very well recorded in facies deposits. Nevertheless, we must take into account these processes and their variations insofar as strong changes of geostrophic circulation occur during the Neogene (Kennett, 1982) and three major events have taken place and are recorded in Miocene deposits at Site 659 .

\section{METHODS}

The purpose of this paper is (1) to analyze the lithologic features of the three kinds of sediments: pelagic cyclic sediments, siliciclastic dark layers and foraminifer-rich ooze layers; (2) to determine, for each 


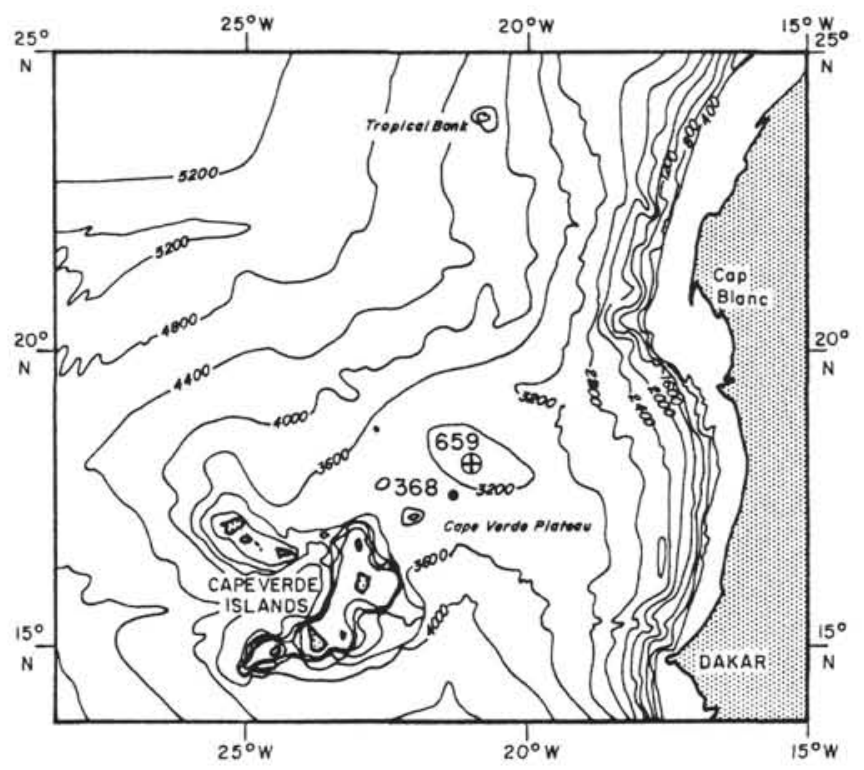

Figure 1. Site 659 and DSDP Site 368 locations. Contours are in meters.

of them, transport and deposit processes and supply sources; and (3) to know their stratigraphic distribution and character evolution throughout the Neogene in order to infer oceanographic or continental variations on the neighboring areas (e.g., climate, volcanic activity).

Only a few samples of typical pelagic sediments and coarsegrained foraminifer ooze were collected. But nearly all of the dark layers were sampled in $2-\mathrm{cm}^{3}$ samples and sediment slides. Sediment slides have been indurated to obtain thin sections of the coarsest sediments just at the basis of these dark layers. For all of them, we have performed structural and microstructural, textural, and component analysis with a binocular microscope, a scanning electron microscope (SEM), and an X-ray diffractometer (see Faugères et al., this vol., for further details on analysis methods).

\section{SEQUENCE CHARACTERISTICS \\ Pelagic and Hemipelagic Deposits: "Climatic Sequence"}

Cycles of pelagic or hemipelagic sediments are documented by shipboard results (Ruddiman, Sarnthein, et al., 1988) and additional analyses in the Bordeaux laboratory. They are composed of two lithologic terms that differ in their colors, carbonate content, and siliciclastic content. In Unit I, where all the dark layers studied are interbedded except for one, the clearest colored term is light gray foraminifer-bearing (or foraminifer) nannofossil ooze with minor amounts of silt and clay, and the darkest term is greenish gray to light olive foraminifer-bearing and/or silt-bearing nannofossil ooze and muddy nannofossil ooze or nannofossil mud.

Carbonate values vary between $65 \%$ and $90 \%$ for the clear term and between $40 \%$ and $60 \%$ for the dark term (Table 1). Usually, the median diameter ranges from 2 to $5 \mu \mathrm{m}$. The sandy fraction is composed of planktonic foraminifers associated with very few benthic foraminifers; it represents around $5 \%-20 \%$ of bulk sediment in the clear term and $0.5 \%-10 \%$ in the dark term (shipboard smear slide analysis). Siliciclastic silty and clayey materials range from $10 \%$ to $30 \%$ and from $40 \%$ to $60 \%$, respectively. Siliciclastic material consists mainly of very fine silty quartz and clay minerals.

We observed no significant variations between clay mineral assemblages of the two terms of one pelagic cycle, but important changes do occur between pelagites of different

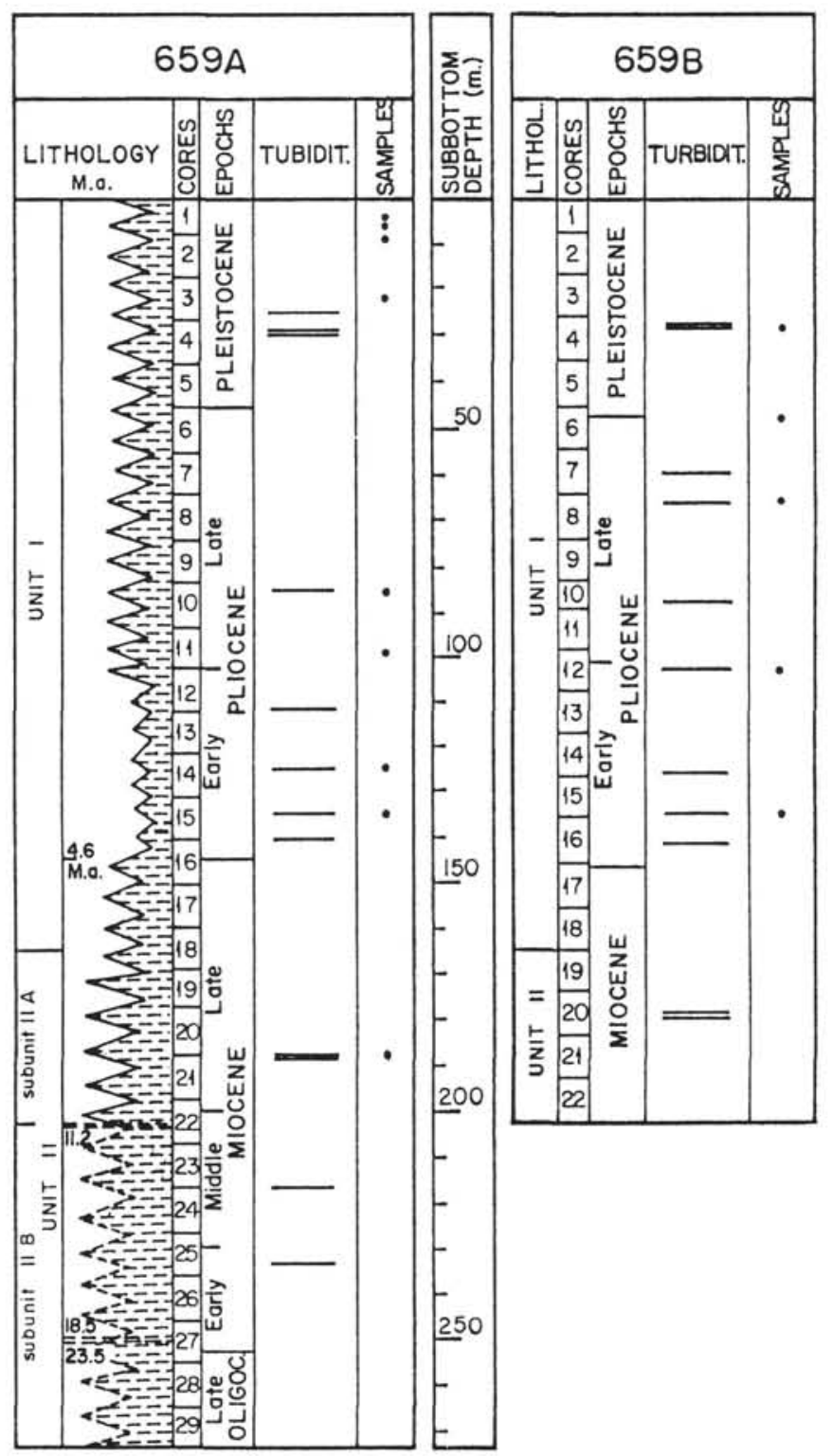

Figure 2. Lithology and stratigraphy of Neogene deposits at Holes 659A and 659B (from Ruddiman, Sarnthein, et al., 1988). Distribution of sandy-silty dark turbiditic layers and location of the studied samples.

ages. These deposits are the only ones where noticeable amounts of attapulgite have been observed (Table 2). In one sample (Section 108-659A-1H-5, 115-121 cm; Fig. 3A and Table 1), silts are predominant with a median diameter of 8 or $9 \mu \mathrm{m}$ and the sediment is well to very well sorted; such material is assumed to contain eolian dusts (Sarnthein and Koopmann, 1980). Figure 3A highlights the variability of grain-sized characteristics of different pelagic or hemipelagic sediments.

According to sedimentary features, these two-term cycles could be interpreted as sequences composed of a dark basal term overlain by a clear term (Fig. 4A and Plate 1, Fig. 3). The basal contact with the underlying sequence seems rather sharp with a very thin color gradation, usually strongly bioturbated; on the other side, the transition between the two terms of one sequence is very much gradual and is underlain by green or black-purple laminations of diagenetic origin (monosulfide?). 
Table 1. Structural, textural, and component characteristics of the sequences studied at Holes 659A and 659B.

\begin{tabular}{|c|c|c|c|c|c|c|c|c|c|c|c|c|c|c|c|c|c|c|c|}
\hline 1 & 2 & 3 & 4 & 5 & 6 & 7 & 8 & 9 & 10 & 11 & 12 & 13 & 14 & 15 & 16 & 17 & & \begin{tabular}{|l|}
18 \\
\end{tabular} & \multirow{2}{*}{ 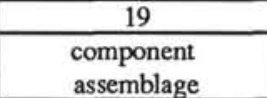 } \\
\hline $\begin{array}{l}\text { sequence } \\
\text { number }\end{array}$ & type & terms & samples & $\begin{array}{c}\% \\
\mathrm{CaCo} 3\end{array}$ & $\begin{array}{c}\% \\
>150 u m\end{array}$ & $\begin{array}{c}\% \\
<63 \text { um } \\
\end{array}$ & $\begin{array}{c}\% \\
\text { clay }\end{array}$ & Md um & sorting & $\mathrm{F} / \mathrm{O}$ & \multicolumn{8}{|c|}{ sandy components } & \\
\hline $\begin{array}{c}659 \mathrm{~A}-1 \mathrm{H} 3 \\
82-88 \mathrm{~cm}\end{array}$ & contourite & $\begin{array}{l}\text { "dark" } \\
\text { "clear" }\end{array}$ & $\begin{array}{l}82-85 \\
85-88 \\
\end{array}$ & $\begin{array}{l}45 \\
63 \\
\end{array}$ & $\begin{array}{l}12 \\
20 \\
\end{array}$ & $\begin{array}{l}72 \\
68 \\
\end{array}$ & $\begin{array}{l}26 \\
17 \\
\end{array}$ & $\begin{array}{l}14 \\
16 \\
\end{array}$ & $\begin{array}{c}21 \\
2 \\
\end{array}$ & $\begin{array}{l}0.4 \\
0.3\end{array}$ & - & - & - & - & - & $\begin{array}{l}\text { P. } \\
100 \\
100\end{array}$ & B. & - & Biog. > Silic. \\
\hline \begin{tabular}{|c|}
$659 \mathrm{~A}-1 \mathrm{H}-5$ \\
$115-121$ \\
\end{tabular} & $\begin{array}{c}\text { hemi } \\
\text { pelagite }\end{array}$ & $\begin{array}{l}\text { dark } \\
\text { dark }\end{array}$ & $\begin{array}{l}116-118 \\
118-121\end{array}$ & $\begin{array}{l}43 \\
30\end{array}$ & 5 & $\begin{array}{l}82 \\
94\end{array}$ & $\begin{array}{l}10 \\
25\end{array}$ & $\begin{array}{l}9 \\
8\end{array}$ & $\begin{array}{l}2.4 \\
2.8\end{array}$ & 0.6 & $\begin{array}{l}5 \\
5\end{array}$ & - & - & - & - & $\begin{array}{l}95 \\
95\end{array}$ & & - & $\begin{array}{l}\text { Silic. > Biog. } \\
\text { eolian dust }\end{array}$ \\
\hline \begin{tabular}{|c|}
$659 \mathrm{~A}-2 \mathrm{H}-1$ \\
$124-130$ \\
\end{tabular} & pelagite & $\begin{array}{l}\text { clear } \\
\text { dark }\end{array}$ & $\begin{array}{l}124-127 \\
127-130 \\
\end{array}$ & $\begin{array}{l}66 \\
60 \\
\end{array}$ & - & $\begin{array}{l}99,5 \\
99,5\end{array}$ & $\begin{array}{l}40 \\
45\end{array}$ & $\begin{array}{l}26 \\
2\end{array}$ & $\begin{array}{l}1.9 \\
1,7 \\
\end{array}$ & 0,3 & $<5$ & - & - & - & - & \begin{tabular}{|l|}
75 \\
70 \\
\end{tabular} & $\begin{array}{l}15 \\
15 \\
\end{array}$ & \begin{tabular}{|l|}
10 \\
10 \\
\end{tabular} & Biog. > Silic. \\
\hline \begin{tabular}{|c|}
$659 \mathrm{~A}-3 \mathrm{H}-3$ \\
$25-31$ \\
\end{tabular} & contourite & & $\begin{array}{l}25-28 \\
28-31 \\
\end{array}$ & $\begin{array}{l}73 \\
63 \\
\end{array}$ & $\begin{array}{c}8 \\
14 \\
\end{array}$ & $\begin{array}{l}80 \\
74\end{array}$ & $\begin{array}{l}23 \\
25\end{array}$ & $\begin{array}{l}11 \\
14\end{array}$ & $\begin{array}{c}2 \\
2,3\end{array}$ & $\begin{array}{l}0,4 \\
0,5\end{array}$ & - & - & - & - & - & $\begin{array}{c}100 \\
100 \\
\end{array}$ & - & - & Biog. > Silic. \\
\hline \begin{tabular}{|c|}
$659 \mathrm{~B}-4 \mathrm{H}-01$ \\
and $4 \mathrm{H}-02$
\end{tabular} & turbidite & - & g. $6 \ldots .$. & 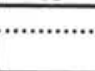 & & 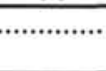 & & 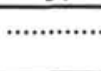 & , & & & & & & & & 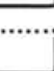 & & Volcanic \\
\hline 659B-6H-02 & hemi-pelagite & & $\begin{array}{l}71-74 \\
74-77\end{array}$ & $\begin{array}{l}20 \\
10\end{array}$ & $\begin{array}{l}0,5 \\
0,5\end{array}$ & $\begin{array}{l}98 \\
97\end{array}$ & $\begin{array}{l}25 \\
20\end{array}$ & $\begin{array}{c}4 \\
4,5\end{array}$ & $\begin{array}{c}2,2 \\
2\end{array}$ & 0,6 & - & - & - & - & - & $\begin{array}{l}100 \\
100\end{array}$ & & - & Silic. $\gg$ Biog. \\
\hline $\begin{array}{c}659 \mathrm{~B}-8 \mathrm{H}-02 \\
133-136\end{array}$ & $\begin{array}{l}\text { turbidite } \\
\text { pelagite }\end{array}$ & $\begin{array}{c}2 \\
2 \\
1 \\
\text { clear }\end{array}$ & \begin{tabular}{|c|}
$131-133$ \\
$133-136$ \\
$136-136,5$ \\
$136,5-137$
\end{tabular} & $\begin{array}{c}30 \\
43 \\
0 \\
46\end{array}$ & - & $\begin{array}{c}100 \\
99 \\
\text { i ro n } \\
98\end{array}$ & $\begin{array}{c}47 \\
25 \\
-0 x x \\
14\end{array}$ & $\begin{array}{c}2,3 \\
3,5 \\
\mathrm{~d} \mathrm{e} \\
5,5\end{array}$ & $\begin{array}{c}3 \\
2,3\end{array}$ & 1 & $\begin{array}{l}\text { tr } \\
5 \\
\text { tr } \\
-\end{array}$ & $\begin{array}{l}- \\
\text { tr } \\
- \\
-\end{array}$ & $\begin{array}{l}5 \\
5 \\
\text { tr } \\
-\end{array}$ & $\begin{array}{l}- \\
\text { tr } \\
\text { tr } \\
-\end{array}$ & tr & $\begin{array}{l}95 \\
85 \\
100\end{array}$ & $\begin{array}{l}\text { tr } \\
5\end{array}$ & - & Silic.+(Volc?) $>$ Biog \\
\hline \begin{tabular}{|c|}
$659 \mathrm{~A}-10 \mathrm{H}-02$ \\
$86-92$ \\
\end{tabular} & turbidite & $\begin{array}{l}3 \\
2 \\
\end{array}$ & $\begin{array}{l}86-89 \\
89-92 \\
\end{array}$ & $\begin{array}{l}45 \\
40 \\
\end{array}$ & - & $\begin{array}{l}97 \\
99 \\
\end{array}$ & $\begin{array}{l}55 \\
55 \\
\end{array}$ & $\begin{array}{l}1,9 \\
1,6 \\
\end{array}$ & $\begin{array}{l}3,2 \\
3,7 \\
\end{array}$ & 0,4 & tr & - & - & - & 5 & $\begin{array}{l}100 \\
80 \quad 1\end{array}$ & & - & Silic. > Biog. \\
\hline $\begin{array}{c}659 \mathrm{~A}-11 \mathrm{H}-04 \\
64-101\end{array}$ & pelagite & $\begin{array}{c}\text { clear } \\
5 Y 8 / 1 \\
5 Y 8 / 1 \\
\text { dark } \\
5 Y 7 / 1 \\
5 Y 7 / 1\end{array}$ & $\begin{array}{c}64-65 \\
73-74 \\
81-82 \\
89-90 \\
95-96 \\
100-101\end{array}$ & $\begin{array}{l}80 \\
81 \\
74 \\
56 \\
46 \\
55\end{array}$ & $\begin{array}{c}13,4 \\
13,8 \\
15,6 \\
4,6 \\
2,6 \\
3,8\end{array}$ & $\begin{array}{c}80 \\
73,5 \\
75 \\
92 \\
93,4 \\
90\end{array}$ & $\begin{array}{l}25 \\
25 \\
30 \\
45 \\
50 \\
50\end{array}$ & $\begin{array}{c}5 \\
5 \\
7 \\
2,1 \\
2 \\
2.2\end{array}$ & $\begin{array}{c}2,9 \\
2,6 \\
2,4 \\
3,1 \\
3,5 \\
3\end{array}$ & 1 & $\begin{array}{l}- \\
- \\
-\end{array}$ & $\begin{array}{l}\bar{i} \\
. \\
.\end{array}$ & - & $\begin{array}{l}- \\
\text { tr } \\
- \\
-\end{array}$ & - & $\begin{array}{c}100 \\
100 \\
100 \\
100 \\
100 \\
100\end{array}$ & - & - & Biog. = Silic. \\
\hline $\begin{array}{c}659 \mathrm{~B}-12 \mathrm{H}-4 \\
136-142\end{array}$ & $\begin{array}{l}\text { turbidite } \\
\text { pelagite }\end{array}$ & $\begin{array}{c}2 \\
1+2 \\
?\end{array}$ & $\begin{array}{l}136-138 \\
138-141 \\
141-142\end{array}$ & $\begin{array}{l}35 \\
31 \\
60\end{array}$ & 4,5 & $\begin{array}{c}99,5 \\
99 \\
90\end{array}$ & $\begin{array}{l}55 \\
60 \\
40\end{array}$ & $\begin{array}{l}1,6 \\
2 \\
3\end{array}$ & $\begin{array}{l}2,8 \\
3,5 \\
3,1\end{array}$ & 1 & $\begin{array}{l}15 \\
15 \\
-\end{array}$ & i. & - & - & tr & $\begin{array}{c}85 \\
80 \\
100\end{array}$ & 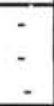 & : & Silic.> Biog. \\
\hline $\begin{array}{c}659 \mathrm{C}-5 \mathrm{H}-5 \\
5-9\end{array}$ & $\begin{array}{l}\text { turbidite } \\
\text { pelagite }\end{array}$ & $\begin{array}{c}2 \\
1 \\
\text { clear }\end{array}$ & $\begin{array}{c}5-9 \\
9-10 \\
10-11\end{array}$ & $\begin{array}{l}33 \\
20 \\
45\end{array}$ & - & $\begin{array}{l}99 \\
74 \\
96\end{array}$ & $\begin{array}{l}60 \\
30 \\
25\end{array}$ & $\begin{array}{c}1,5 \\
16 \\
5\end{array}$ & $\begin{array}{l}2,8 \\
3,6 \\
2,4\end{array}$ & 0,8 & $\begin{array}{l}5 \\
5\end{array}$ & . & - & - & tr & $\begin{array}{l}95 \\
90\end{array}$ & - & tr & Silic. > Biog. \\
\hline $\begin{array}{c}659 \mathrm{~A}-14 \mathrm{H}-3 \\
50-54\end{array}$ & $\begin{array}{l}\text { turbidite } \\
\text { pelagite }\end{array}$ & $\begin{array}{l}1+2 \\
\text { clear }\end{array}$ & $\begin{array}{l}50-52 \\
52-54\end{array}$ & $\begin{array}{l}30 \\
65\end{array}$ & 3 & $\begin{array}{l}93 \\
98\end{array}$ & $\begin{array}{l}12 \\
24\end{array}$ & $\begin{array}{l}6 \\
4\end{array}$ & $\begin{array}{l}2,4 \\
2,2\end{array}$ & 1 & $\begin{array}{l}5 \\
\mathrm{tr}\end{array}$ & - & . & tr & $\begin{array}{l}\mathrm{tr} \\
\mathrm{tr}\end{array}$ & $\begin{array}{c}90 \\
95,5\end{array}$ & 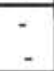 & tr & Silic. > Biog. \\
\hline $659 \mathrm{~A}-15 \mathrm{H}-3$ & $\begin{array}{l}\text { turbidite } \\
\text { pelagite }\end{array}$ & $\begin{array}{c}3 \\
2 \\
1 \\
\text { clear }\end{array}$ & $\begin{array}{c}97-99 \\
99-100 \\
100-101 \\
101-103\end{array}$ & $\begin{array}{l}60 \\
30 \\
33 \\
70 \\
\end{array}$ & $\begin{array}{c}- \\
- \\
4 \\
2,3\end{array}$ & $\begin{array}{c}96 \\
98,5 \\
90 \\
96\end{array}$ & $\begin{array}{l}55 \\
48 \\
25 \\
35\end{array}$ & $\begin{array}{c}1,7 \\
2,3 \\
7 \\
2,9\end{array}$ & $\begin{array}{c}2 \\
2,2 \\
3,6 \\
2,4\end{array}$ & 0,6 & $\begin{array}{l}70 \\
25 \\
10\end{array}$ & . & - & - & 5 & $\begin{array}{l}30 \\
65 \\
85 \\
\end{array}$ & $\therefore$ & $\begin{array}{l}5 \\
5 \\
\text { tr }\end{array}$ & Silic. > Biog. \\
\hline \begin{tabular}{|c|}
$659 \mathrm{~B}-15 \mathrm{H}-6$ \\
$84-109$ \\
$-15 \mathrm{H}-7,4-11$ \\
\end{tabular} & turbidite & & ......fig. 5 & & & & & & & & & & & & & & & & Silic. > Biog. \\
\hline
\end{tabular}

Note: Column 11 = "F/Q": feldspar-quartz ratio evaluated from bulk sediments, Column 12 = "O": quartz percentage of the sandy fraction. Column $13=$ " $\mathrm{F}$ : : feldspar percentage of the sandy fraction. Column $14=$ "Volc.": volcanic grain percentage of the sandy fraction. Column $15=$ "Gyp": gypsum grain in the sandy fraction (tr. = traces). Column $16=$ "Pyr": pyrite. Columns 17 and $18:$
biogenic sandy particle percentages (for. = foraminifers, $\mathrm{P}=$ pelagic foraminifers, $\mathrm{B}=$ benthic foraminifers, and Ech = echinids). In Columns $5-16$, a dash = no data; in Columns 17 and 18 , a dash 
Table 2. Clay mineral assemblages in the different sequences studied at Holes 659A and 659B.

\begin{tabular}{|c|c|c|c|c|c|c|c|c|c|c|c|c|c|c|}
\hline 1 & 2 & 3 & 4 & 5 & 6 & 7 & 8 & 9 & 10 & 11 & 12 & 13 & \multirow{3}{*}{\multicolumn{2}{|c|}{ epochs }} \\
\hline sequence & & & & & \multicolumn{6}{|c|}{ minerals } & \multirow[b]{2}{*}{ assemblage } & \multirow[b]{2}{*}{ type } & & \\
\hline number & type & term & samples & $\% \operatorname{co} 3 \mathrm{Ca}$ & $\%$ & $\mathrm{~S}$ & I & $\mathrm{K}$ & C & A & & & & \\
\hline $659 \mathrm{~A}-1 \mathrm{H}-3$ & contourite & & $82-85$ & 45 & 26 & 29 & 24 & 28 & 10 & 9 & $\mathrm{~S}+\mathrm{I}+\mathrm{K}$ & \multirow[t]{2}{*}{4} & \multirow{11}{*}{\multicolumn{2}{|c|}{$\begin{array}{l}\text { P } \\
\text { L } \\
\text { E } \\
\text { I } \\
\text { S } \\
\text { T } \\
\text { O } \\
\text { C } \\
\text { E } \\
\text { N } \\
\text { E }\end{array}$}} \\
\hline $82-88$ & & & $85-88$ & 63 & 17 & 27 & 27 & 25 & 14 & 7 & & & & \\
\hline $\begin{array}{c}659 \mathrm{~A}-1 \mathrm{H}-5 \\
115-121\end{array}$ & hemipelagite & dark & $118-121$ & 30 & 25 & 37 & 23 & 35 & 5 & - & $\mathrm{S}+\mathrm{K}>\mathrm{I}$ & 3 & & \\
\hline $\begin{array}{c}659 \mathrm{~A}-2 \mathrm{H}-1 \\
124-130\end{array}$ & pelagite & dark & $127-130$ & 60 & 45 & 53 & 10 & 18 & 4 & 15 & $\mathrm{~S} \gg \mathrm{K}+\mathrm{A}+\mathrm{I}$ & 3 & & \\
\hline $659 \mathrm{~A}-3 \mathrm{H}-3$ & contourite & & $25-28$ & 73 & 23 & 30 & 27 & 26 & 10 & 7 & $\mathrm{~S}+\mathrm{I}+\mathrm{K}$ & 4 & & \\
\hline $25-31$ & & & $28-31$ & 63 & 25 & 25 & 25 & 30 & 10 & 10 & & & & \\
\hline \multirow[t]{5}{*}{$659 \mathrm{~B}-4 \mathrm{H}-1$} & pelagite & clear & $98-99$ & 60 & 40 & 25 & 36 & 30 & 9 & tr & $\mathrm{S}+\mathrm{I}+\mathrm{K}$ & 4 & & \\
\hline & pelagite & clear & $115-116$ & 78 & 45 & 31 & 25 & 26 & 10 & 8 & & 4 & & \\
\hline & pelagite & dark & $135-136$ & 76 & 35 & 29 & 29 & 33 & 9 & tr & & 4 & & \\
\hline & turbidite & 4 & $145-146$ & 65 & 45 & 36 & 28 & 26 & 10 & tr & $\mathrm{S}>\mathrm{I}>\mathrm{K}$ & 4 & & \\
\hline & turbidite & 3 & $2-3$ & 38 & 41 & 45 & 31 & 14 & 12 & tr & & & & \\
\hline $\begin{array}{c}659 \mathrm{~B}-6 \mathrm{H}-2 \\
70-77\end{array}$ & hemipelagite & & $71-74$ & 20 & 25 & 17 & 33 & 30 & 3 & 17 & $\mathrm{I}+\mathrm{K}>\mathrm{S}=\mathrm{A}$ & 5 & \multirow{6}{*}{. } & \multirow{3}{*}{$\begin{array}{r}2.6 \\
\text { M.a. }\end{array}$} \\
\hline $\begin{array}{c}659 \mathrm{~B}-8 \mathrm{H}-2 \\
133-136\end{array}$ & turbidite & 2 & $133-136$ & 43 & 25 & 24 & 24 & 30 & 10 & 12 & $\mathrm{~S}+\mathrm{I}+\mathrm{K}$ & 4 & & \\
\hline $\begin{array}{c}659 \mathrm{~A}-10 \mathrm{H}-2 \\
86-92 \\
\end{array}$ & turbidite & 2 & $89-92$ & 45 & 60 & 47 & 14 & 27 & 6 & 6 & $\mathrm{~S}>\mathrm{K}>\mathrm{I}$ & 3 & & \\
\hline \multirow{3}{*}{$\begin{array}{c}659 \mathrm{~A}-11 \mathrm{H}-4 \\
64-101\end{array}$} & pelagite & clear & $64-65$ & 83 & 25 & 30 & 18 & 35 & 10 & 7 & \multirow[t]{3}{*}{$\mathrm{K}+\mathrm{S}>\mathrm{I}$} & \multirow[t]{3}{*}{2} & & P \\
\hline & & clear & $81-82$ & 74 & 15,6 & 31 & 22 & 30 & 10 & 7 & & & & L \\
\hline & & dark & $95-96$ & 46 & 50 & 30 & 26 & 36 & 8 & tr & & & & I \\
\hline $659 \mathrm{~B}-12 \mathrm{H}-4$ & turbidite & 2 & $136-138$ & 35 & 55 & 30 & 23 & 40 & 7 & tr & $\mathrm{K}>\mathrm{S}>\mathrm{I}$ & 2 & & $\mathrm{C}$ \\
\hline $136-142$ & & $1+2$ & $138-141$ & 31 & 60 & 27 & 24 & 40 & 7 & $\mathrm{TR}$ & & & & E \\
\hline $659 \mathrm{C}-5 \mathrm{H}-5$ & turbidite & 2 & $5-9$ & 33 & 60 & 29 & 19 & 40 & 7 & 5 & $\mathrm{~K}>\mathrm{S}>\mathrm{I}$ & 2 & $\mathrm{e}$ & $\mathrm{N}$ \\
\hline $5-11$ & & clear & 95-96 & 46 & 50 & 30 & 26 & 36 & 8 & tr & & & a & E \\
\hline $659 \mathrm{~A}-14 \mathrm{H}-3$ & turbidite & $1+2$ & $50-52$ & 30 & 12 & 30 & 17 & 40 & 6 & 7 & $\mathrm{~K}>\mathrm{S}>\mathrm{I}$ & 2 & $r$ & \\
\hline $50-54$ & & pelagite & $52-54$ & 65 & 24 & 25 & 25 & 40 & 10 & tr & & & $\mathrm{i}$ & \\
\hline \multirow[t]{2}{*}{ 659A-15H-6 } & & pelagite & $84-85$ & 84 & 25 & 25 & 28 & 40 & 7 & tr & $\mathrm{K}>\mathrm{S}+\mathrm{I}$ & 2 & \multirow{2}{*}{\multicolumn{2}{|c|}{$y$}} \\
\hline & turbidite & 4 & $144-145$ & 60 & 35 & 33 & 19 & 40 & 9 & tr & $\mathrm{K}>\mathrm{S}>\mathrm{I}$ & 2 & & \\
\hline \multirow[t]{3}{*}{$15 \mathrm{H}-7$} & & 3 & $5-7$ & 33 & 55 & 35 & 18 & 40 & 7 & tr & & & & \\
\hline & & 2 & $7-8$ & 45 & 45 & 32 & 20 & 40 & 8 & tr & & & & \\
\hline & & 1 & $7-9,5$ & 28 & 25 & 42 & 16 & 34 & 8 & - & $\mathrm{S}>\mathrm{K} \gg>\mathrm{I}$ & 3 & & \\
\hline $659 \mathrm{~A}-20 \mathrm{H}-6$ & turbidite & 2 & $85-87$ & 15 & 55 & 15 & 21 & 60 & 4 & tr & $\mathrm{K} \gg \mathrm{S}+\mathrm{I}$ & 1 & \multirow{2}{*}{\multicolumn{2}{|c|}{ MIOCENE }} \\
\hline $83-89$ & & & & & & & & & & & & & & \\
\hline
\end{tabular}

Note. Column 6: clay percentage in bulk sediment. Columns 7-11: clay mineral percentage in the clay fraction $(\mathrm{S}=\mathrm{smectitie}, \mathrm{I}=$ illite $, \mathrm{K}=\mathrm{kaolinite}, \mathrm{C}=$ chlorite, and $\mathrm{A}=$ attapulgite $[\mathrm{tr}=$ traces of attapulgite]). Types $1-5$ in column 13 refer to different clay mineral assemblages (see text).

These sequences range from 25 to $140 \mathrm{~cm}$; they represent time intervals of $10-90$ k.y. that match the orbital periodicity used by Milankovitch and numerous other authors to explain the forcing function of climatic changes (Ruddiman, Sarnthein, et al., 1988). We have to keep in mind all these features in order to distinguish tentatively a climatic sequence from turbidite or contourite sequences.

\section{Siliciclastic Dark Layers: Turbidite Sequences}

Siliciclastic layers interbedded in pelagic sediments are neither frequent (about 12 layers throughout the Neogene deposits) nor coarse grained ( $28 \mu \mathrm{m}$ for the coarsest median diameter). They are well underlined, however, by a basal erosional surface and a conspicuous upward color gradation that goes from very dark sediment at the basis to a white gray colored facies at the top. This gradation emphasizes a vertical sequence of facies in which we may recognize a turbidite sequence.

\section{Lithology}

The most complete sequence we have observed can be subdivided into four superimposed layers. These layers, or lithologic subdivisions, are called "terms" in the following sections (Figs. 3B and 3C, 4C, 5, and 6; Table 1; and Plates 1 and 2).

\section{Term 1}

At the basis of Term 1, there is a thin dark layer (a few millimeters to $2 \mathrm{~cm}$ thick) composed of mixed silt, clay, and sand of terrigenous or volcanogenic origin and with a low percentage $(5 \%-30 \%)$ of carbonate skeleton (foraminifer and nannofossil). Except for the sharp, commonly scoured base, there generally are no internal sedimentary structures (Plate 2). Only a few layers display microlaminations of alternating foraminifer ooze and silty quartz-rich sediment (Plate 1, Figs. 1 and 2). This material is fine grained with a median diameter ranging from 7 to $28 \mu \mathrm{m}$ and a sandy fraction accounting for $5 \%-26 \%$ in the coarsest observed layer.

\section{Term 2}

Above Term 1, Term 2 consists of dark gray clayey silts or silty clay, with a thickness ranging from 3 to $15 \mathrm{~cm}$. Sediment is generally more fine grained with an increase of the clay fraction. The median diameter varies from $12 \mu \mathrm{m}$ for the 

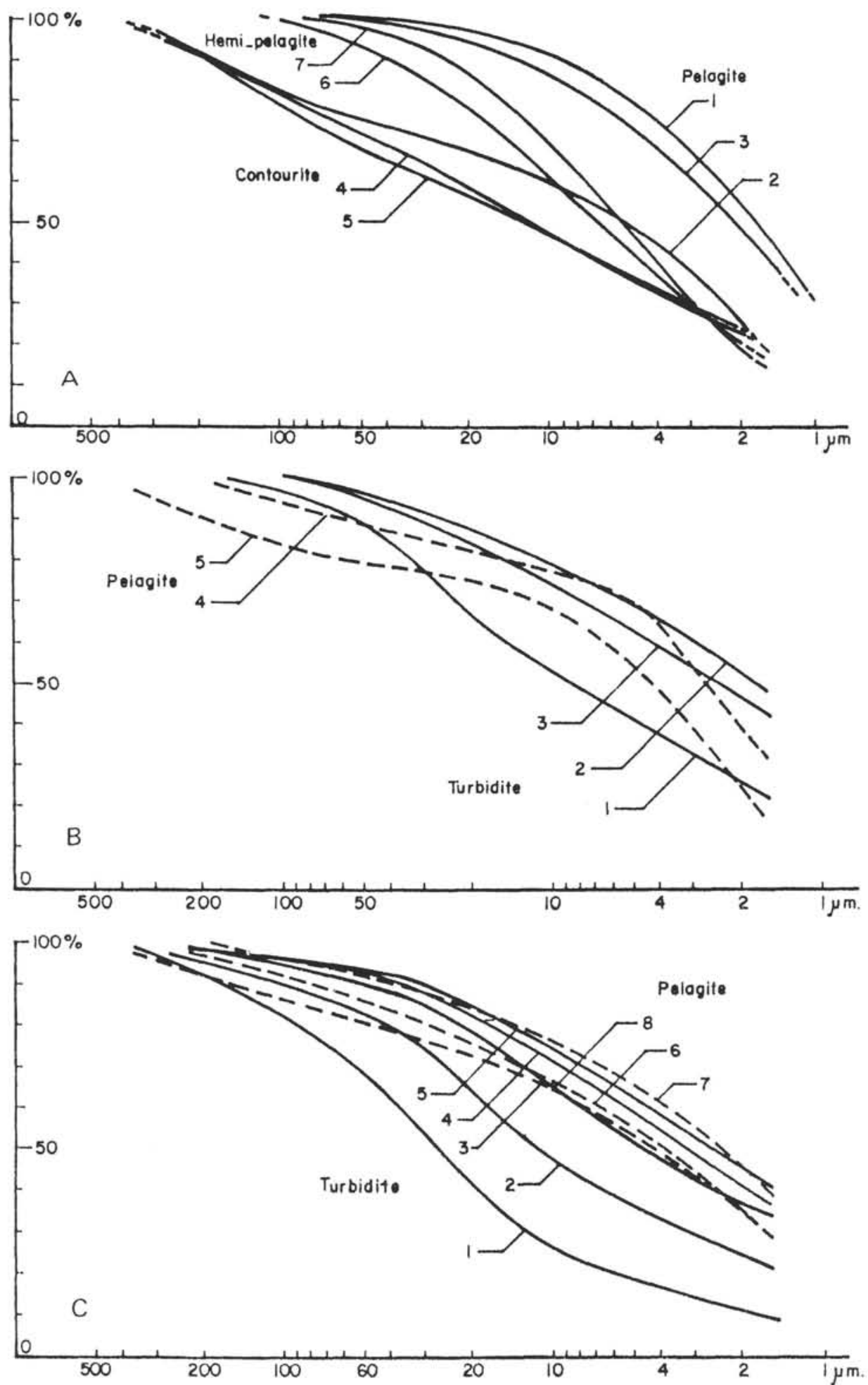

Figure 3. Grain-size cumulative frequency curves plotted on semilogarithmic paper for the main sediment types. A. Climatic sequence (pelagite): Section 108-659A-2H-1, 127-130 cm, dark term (line 1); Section 108-659A-11H-4, 73-74 cm, clear term (line 2); Section 108-659A-11H-4, 100-101 $\mathrm{cm}$, dark term (line 3). Climatic sequence (hemipelagite): Section 108-659A-1H-5, 118-121 cm, dark term with eolian dust (line 6); Section 108-659B-6H-2, 75-77 cm, dark term (line 7). Contourite sequence: Section 108-659A-3H-3, 28-31 cm (line 4); Section 108-659A-1H-3, 82-85 cm (line 5). B. Turbidite sequence with quartz-rich siliciclastic material: Section 108-659B-15H-7, 8-9.5 cm, term 1 (line 1); 7-8 cm, term 2 (line 2); and 5-7 cm, term 3 (line 3); Section 108-659B-15H-6, 139-140 cm, term 4 (line 4); and 108-109 cm, pelagite (line 5). C. Volcaniclastic turbidite sequence: Section 108-659B-4H-2, 12-13 cm, term 1 (line 1); 8-10 cm, term 2 (line 2); $135-136 \mathrm{~cm}$, pelagite (line 6); $125-126 \mathrm{~cm}$, pelagite (line 7); and $105-106 \mathrm{~cm}$, pelagite (line 8). 


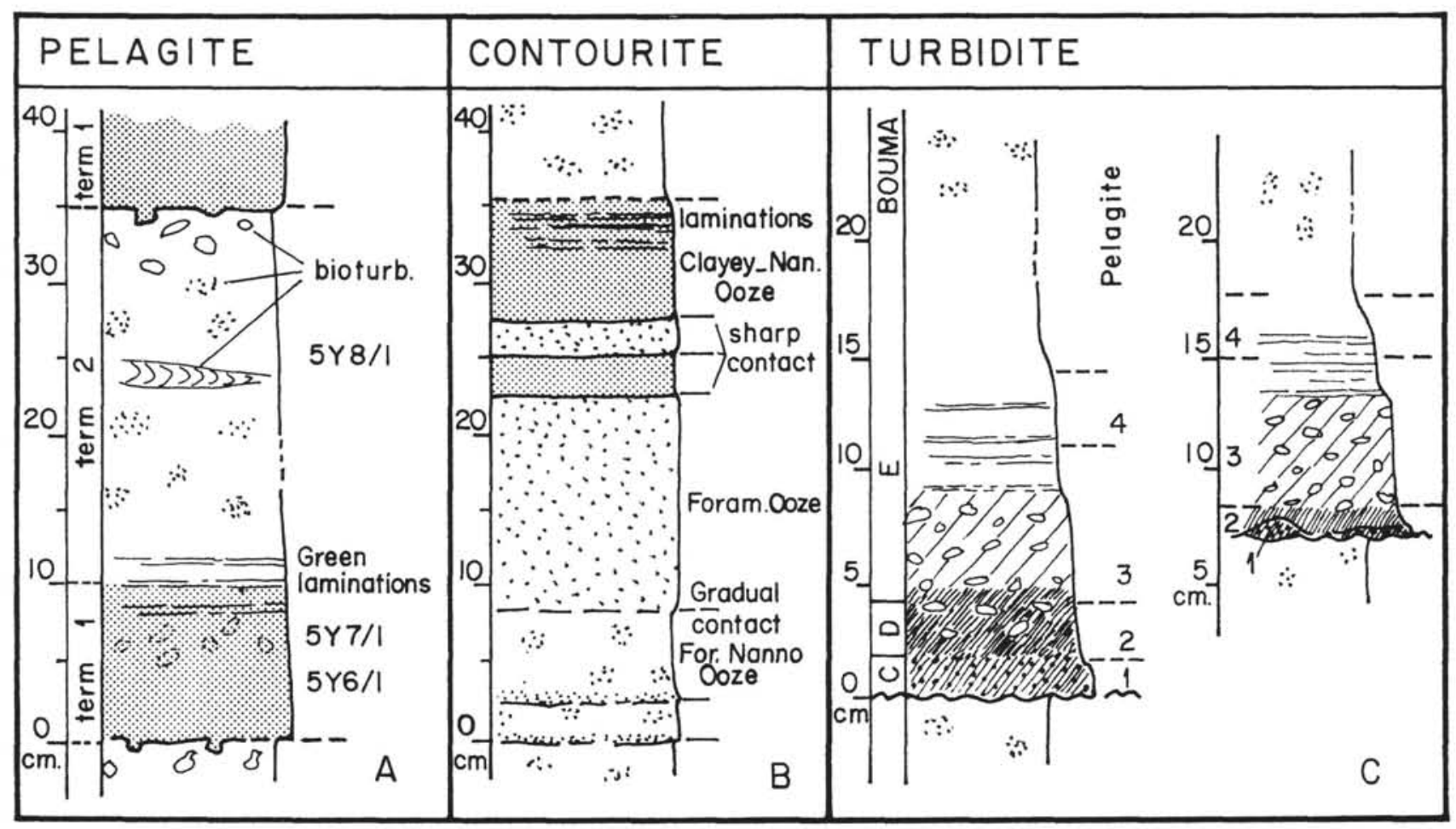

Figure 4. The different sequences in Site 659 deposits. A. Pelagite. B. Contouritic. C. Turbiditic.

coarsest studied sample to less than $2 \mu \mathrm{m}$. Carbonate contents are a little more important $(15 \%-30 \%)$ than in Term 1 and components of the sandy fraction are similar. This term shows no structures of dynamic origin but presents striking bioturbations (Chondrites, Planolites, Scolicia?) with white color infill contrasting with the surrounding dark gray silty clay (Plate 2). Contact between Terms 1 and 2 is rather gradational.

\section{Term 3}

Term 3 is a transitional facies between the underlying terrigenous or volcanogenic terms (1 and 2$)$ and the upper Term 4 with predominant pelagic carbonate particles. Its thickness is around $5-15 \mathrm{~cm}$ with a gradual color change (dark gray to light gray) related to a carbonate increase $(40 \%-60 \%)$. Median diameters vary from 2.5 to $4 \mu \mathrm{m}$ and may be slightly coarser than median diameters in the underlying Term 2.

Carbonate particles are predominant in the sandy fraction with terrigenous or volcanogenic material in very low proportions. The lower part of this term is strongly to moderately bioturbated (indistinct mottling). Green diagenetic laminations are often present in the uppermost part of this term and contact between Terms 2 and 3 may be gradual or sharp (Plate 1, Fig. 1, and Plate 2).

\section{Term 4}

Term 4 is a white to white gray ooze, slightly to moderately bioturbated and mainly composed of coccoliths and foraminifers in variable amounts, with significant proportions of silty quartz and clay in some cases. Carbonate percentages show irregular variations with an average of about $70 \%$. Sediment grain size is variable with a median diameter ranging from 2 to $4 \mu \mathrm{m}$.

Sometimes grain size can increase upward, as shown by the sandy fraction of Sample 108-659B-15H-6, 84-149 cm (Fig. 5). At the basis, this fraction accounts for $5 \%-12 \%$ and, at the top, for $17 \%-20 \%$. These characteristics are those of pelagic sediments: a decrease in bottom dynamic processes allows the deposition of calcareous ooze with an upward gradation from turbiditic facies to pelagite.

\section{Discussion and Interpretation}

All these sedimentary characteristics globally follow the upper divisions of the turbidite Bouma sequence (1962) or the fine-grained turbidite model of Stow and Piper (1984):

1. an erosional basal surface;

2. vertical graded bedding at least throughout Terms 1 and 2 ;

3. grain-size cumulative frequency curves (Fig. 3B and 3C), which show an upward gradual change (with "parabolic" curves for Term 1, "hyperbolic" curves for Term 4, and intermediate curves for Terms 2 and 3), indicate a decrease in bottom dynamic intensity (Rivière, 1977); and

4. a gradual transition between turbidite sequence and the overlying pelagic deposits.

In addition, these sedimentary sequences show the following particular features:

1. Term 1, with its sandy-clayey silts, laminated or not, is similar to the top of the Bouma C and D divisions. Term 2, with its bioturbated silty mud, is equivalent to the top of the D division. Usually, however, bioturbations are not so strong in these levels of the Bouma sequence. Only very low-density currents may allow for the survival of benthic fauna during and just after the deposits of the suspended turbiditic material, and we assume that the overlying terms are mainly composed of pelagic particles.

2. Contact between Terms 2 and 3 can sometimes be very sharp (Plate 1, Fig. 1, and Plate 2, Fig. 3). This is difficult to understand if turbidites are deposited by low-density turbidity currents. We assume that these contacts could be due to bottom current activity that prevents deposition of the finest turbidite particles. 


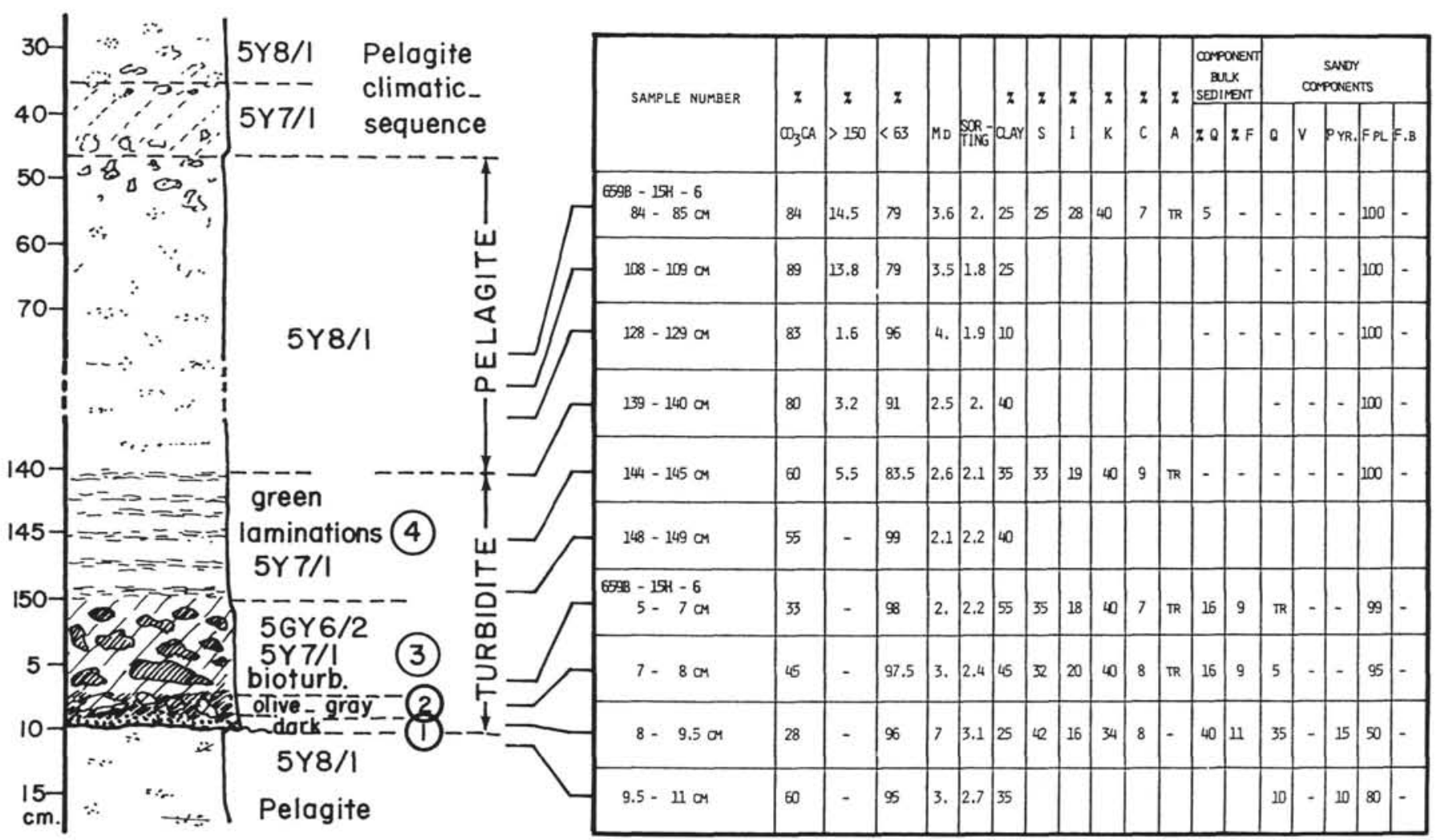

Figure 5. Lithology, grain size, and components of a quartz-rich siliciclastic turbidite (Sections 108-659B-15H-6, 84-149 cm, and 108$659 \mathrm{~B}-15 \mathrm{H}-7,4-11 \mathrm{~cm})$. Dash $=0 \%$; empty squares $=$ no data.

3. Terms 3 and 4 correspond to the E division with a rapid gradation to light gray or white pelagic sediments.

Usually, turbidite sequences are interbedded in light colored ooze and seem to be deposited rather than be a dark term related to a climatic sequence.

\section{Sequence Variations and Components}

Turbidite sequences range in thickness from 15 to $40 \mathrm{~cm}$ and are more or less complete with respect to the complete four term sequences described above. Thus, Term 1 may be absent or reduced to an erosional surface underlined by the horizontal alignment or flattened lenses of silts (Fig. 4C and Plate 2, Figs. 2 and 3).

Furthermore, according to the sandy components, clay assemblages, and carbonate contents of Terms 1 and 2, two types of sequences may be distinguished (Table 1).

1. The first sequence is characterized by major siliciclastic material composed of quartz, feldspar, and clay associated with minor biogenic particles (carbonates from $15 \%$ to $45 \%$; see column labeled "Silic. > Biog." in Table 1; sequence type, Fig. 5; Plate 3, Figs. 2 and 3).

2 . The second sequence is always composed of major siliciclastic material but of volcanic origin (up to $80 \%$ in the sandy fraction). This material is mixed with rare quartz at $5 \%$ and biogenic particles from $10 \%$ to $25 \%$ (see column labeled "volc." in Table 1; sequence type, Fig. 6; Plate 2, Fig. 1; Plate 4; and Plate 5, Figs. 1-4).

\section{Biogenic Particles}

In these two component assemblages, biogenic particles of the sandy fraction are mainly pelagic foraminifers, the most important being the Globigerina group associated with the
Orbulina and Globorotalia groups. In some samples, rare benthic foraminifers or echinid spicules are present.

\section{Siliciclastic Sandy Particles}

Siliciclastic sandy particles are composed of major quartz and minor feldspars. Due to the fine grain size (usually $<150$ $\mu \mathrm{m})$, quartz grains are angular or slightly rounded; a few of them have a pink hue (Plate 3, Fig. 4) and only very few black heavy minerals are present. In a few samples, pyrite is present (>5\%-15\%), sometimes with framboidal or crystalline forms (Plate 5, Fig. 5). Furthermore, in two of the samples, detritic gypsum grains have been observed (Samples 108-659B-8H-2, $138 \mathrm{~cm}$ [Plate 5, Fig. 6] and 108-659A-14H-3, 50-52 cm).

\section{Sandy Volcanic Particles}

A larger variability is noted in sandy volcanic particles. The bulk composition of minerals, ashes, or glass is noted on Plates 4 and 5 (X-ray diagrams).

Volcanic ashes and glass constitute grains of agglomerate microparticles. They constitute more than $60 \%$ of the sandy fraction. These grains show different aspects but with the same composition (Plate 5, Figs. 1-4): dark grains with an irregular surface that are composed mainly of black material, or gray grains that show scattered black particles in a clear microcrystalline matrix. Some grains are true fresh volcanic glass.

Colored, fresh, or exceptionally very well-rounded grains represent $20 \%-25 \%$ of the sandy material. Among them, different types have been identified (Plate 4): brown and green amphiboles (hornblende and basaltic hornblende), yellow pyroxene (augite and ægyrinic augite), zeolites with an iron-rich coating, reddish rutile, and black homogeneous fresh grains that seem to be the detritus of volcanic rocks or glass. 


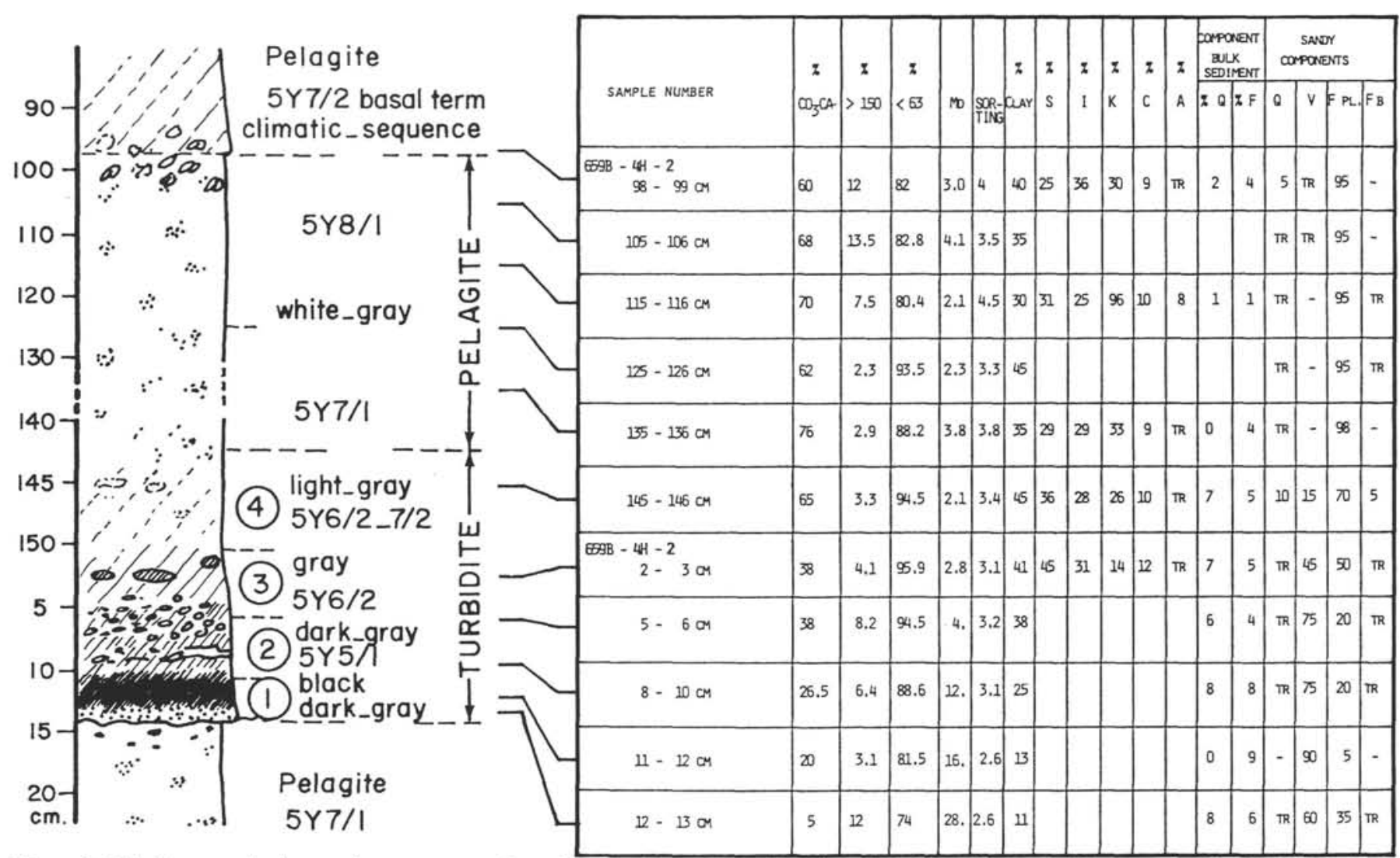

Figure 6. Lithology, grain size, and components of a volcaniclastic sequence (Sections 108-659B-4H-1, 98-150 cm, and 108-659B-4H-2, 0-15 $\mathrm{cm})$. Dash $=0 \%$; empty squares $=$ no data.

Furthermore, quartz grains and plagioclases are also present in very low proportions $(<5 \%)$. They are associated with few biotite and muscovite.

\section{Clay Minerals}

Clay minerals, which are very abundant in Term 2 of the sequences, are composed of the same major minerals (smectite, illite, and kaolinite) than in the underlying or overlying pelagites. These minerals are associated with low amounts of chlorite and an even lower amount of attapulgite (Table 2). No striking changes have been observed between the different terms of one sequence, but the smectite amount seems higher in the turbidite sequence when compared with the pelagite (Samples 108-659B-4H-1, 108-659B-4H-2, 108-659A-14H-3, 108-659A-15H-6, and 108-659A-15H-7; Table 2). This could be the result of dynamic processes. Furthermore, turbidites of different ages show different clay mineral assemblages, and these assemblages seem to have recorded the same stratigraphic distributions as pelagites throughout the Neogene.

\section{CONTOURITE SEQUENCE}

Usually, contourite sequences show a very high variability in their lithologic characteristics (Stow, 1982), and they still remain the most difficult to identify. Although we know bottom currents were flowing in this area at least during the Pleistocene and Holocene, no classical contouritic facies (Nelson et al., 1975; Bouma, 1975; Stow, 1982; Faugères et al., 1984; Gonthier et al., 1984) have been observed. In particular, not one of the fine-grained dark layers has been deposited under bottom current control. The influence of these currents seems to be recorded only in the pelagic ooze when a high foraminifer vs. low nannofossil proportion is observed.

Only two samples were taken in these foraminifer-rich layers and investigated in detail, but several others have been observed during shipboard core description, especially in Sections 108-659A-3H-3 and 108-659A-3H-4. These layers could tentatively be characterized by the following features (Figs. 3A and 4B; Tables 1 and 2; Plate 1, Figs. 4 and 5):

1. interbedding in homogeneous fine-grained pelagite;

2. variable thicknesses ranging from a few centimeters to a few decimeters;

3. sharp contacts at the top and/or the basis, if the sediments are not too strongly bioturbated;

4. no graded bedding;

5. massive or faintly laminated facies, weakly bioturbated (Sections 108-659A-3H-3 and 108-659A-3H-4, VCD);

6 . coarser grain size than in classical pelagic foraminifernannofossil ooze: median diameters from 11 to $16 \mu \mathrm{m}$ compared with $\sim 5 \mu \mathrm{m}$ in pelagites and a sandy fraction accounting for $20 \%-32 \%$ of the bulk sediment;

7. grain-size cumulative frequency curves that are typical of deposition under bottom current processes ("logarithmic" curve, Rivière, 1977) and that correspond to uniform suspension intermediate between true decantation and sorted, finetailed sediments);

8. a sandy fraction composed of only pelagic foraminifers;

9. a carbonate content similar to the pelagite sequences; and

10. a lower clay-size fraction but with the same clay mineral assemblage as in the surrounding sediments. 
These features are clearly different from those of sediments in pelagic climatic sequences and turbidite sequences. According to the usual parameters that differentiate pelagites, turbidites, and contourites (Table 3), they yielded evidence of contourite deposits. These foraminifer sandysilty contourites are mainly interbedded in pelagite. Sometimes, bottom current activity has also been recorded in the upper part of turbidite sequence, as we have previously noted. They are completely different from the fine-grained pelagic or hemipelagic mud investigated by Sarnthein and Mienert (1986) at the surface of modern sediment waves on the northwest African continental rise.

\section{SEQUENCE DISTRIBUTION DURING THE NEOGENE}

At Site 659 , cyclic pelagic deposits account for up to $90 \%$ of the Neogene sediments. Interbedded turbidite or contourite sequences constitute minor and rare events in this sedimentation.

Several typical contourite layers have been recognized, especially in the upper Pleistocene deposits. We did not have the on-board possibility to check and sample all the layers present throughout the sediment pile. However, they could not constitute more than $1 \%-5 \%$ of the overall deposits; they seem more frequent during the Pleistocene (Sections $108-659 \mathrm{~A}-3 \mathrm{H}-3$ and $108-659 \mathrm{~A}-1 \mathrm{H}-3$ ). If that was confirmed, it would provide some evidence for enhanced bottom circulations during this recent period. Nevertheless, except for the three Miocene episodes, during which vigorous bottom circulation changes are suspected to be responsible for hiatuses or major modifications of the sedimentation, our observations fit the assumption that these circulations were rather sluggish on Cape Verde Plateau during the Neogene, with only recent, weak, and temporary increases.

Turbidite sequences account for $\sim 1 \%-2 \%$ of the overall deposits. About 12 sequences have been checked throughout Neogene sediments. They are scattered irregularly but are mainly concentrated in the Pliocene and are rare in the Miocene and very rare in the Pleistocene.

What are the sources of these turbidity currents? Because of a general uplift of the rise (Shipboard Scientific Party, 1978b), the Cape Verde Plateau is higher than the surrounding areas of the continental margin. Since this period, Site 659 , located on the highest topographic part of the Cape Verde Plateau, has not been reached by coarse-grained material transported by direct down-slope processes originating from the Senegalese continental slope. Most of the mass-gravity flows or turbidity currents are channelized by numerous channels (Cayar canyon system and many others; Dietz et al., 1969; Uchupi et al., 1976; Jacobi, 1976; Coumes and Caratini, 1979; Jacobi and Hayes, 1982) and deflected either to the north or south of the Cape Verde Plateau.

Only fine-grained sediments of turbidites may, from time to time, reach this site; these probably occur when highdensity and high-velocity turbidity currents running in neighboring channels are strong enough to overflow channel levees. If these turbidites are composed of major siliciclastic nonvolcanic material, they do originate from the adjacent Senegalese continent and could have recorded continental sources and climatic conditions. If they are mainly composed of volcanic material, however, they might reflect volcanic episodes, which do occur in the Dakar area but are more probable in the adjacent volcanic archipelagos of the Cape Verde Islands (Dillon and Sougy, 1974; Cantagrel et al., 1976; Lancelot and Siebold, 1978; Shipboard Scientific Party, 1978b).

These islands are indeed very close to the investigated area, and the mineralogy of deposits fits this most reasonable assumption. In spite of the fact that we know little about the chemical composition of our samples, their composition is similar to the igneous rocks from the Cape Verde Islands, which are essentially alkalic basalts with scarce trachytes and phonolites (Michell-Thomé, 1972; Rothe and Koch, 1978). We suggest that these turbidites occurred every time island volcanic activity was high: during these events, massive accumulations of volcanic products spread over the narrow shelf and seismic activity, commonly present during volcanic episodes, favored turbidity current triggering.

Major volcanic sand-rich turbidites take place during the early Miocene or at the middle-early Miocene boundary $(\sim 17$ $\mathrm{Ma}$ ) and during the early Pleistocene (about $1 \mathrm{Ma}$ ). Unfortunately, the early Miocene episode has not been sampled or studied in detail; it consists of a unique sequence (Section 108-659A-25X-5), the basis of which is composed of clayey silt with major volcanic material $(85 \%)$ and accessory quartz and nannofossils (shipboard smear slides).

This episode is easy to correlate with volcanic activity occurring at the same time on the Cape Verde Islands (Grunau et al., 1975; Michell-Thomé, 1972). It was previously described from Site 368 and 369 sediment studies (Shipboard Scientific Party, 1978b, 1978c; Gardner et al., 1977; DiesterHaass, 1978; Rothe and Koch, 1978). The episode is also more or less synchronous with the age of diabase sills, intrusive in Cretaceous deposits at Site 368 (Duncan and Jackson, 1978). Nevertheless, no evidence of persistent volcanic activity up to the uppermost Miocene has been recorded at Site 659 by turbidite sequences, as quoted in several works (Cantagrel et al., 1976; Uchupi et al., 1976; Diester-Haass, 1978; Shipboard Scientific Party, 1978a).

The early Pleistocene volcanic episode seems to be more intense because it drives the deposition of two superposed volcaniclastic turbidites (Sections 108-659B-4H-1 and 108$659 \mathrm{~B}-4 \mathrm{H}-2$ ) separated by only $70-\mathrm{cm}$-thick pelagic sediments. No volcanic event seems to have been reported at the same time on the adjacent continental areas, and volcanic activity on the Cape Verde lsland lasted until about $10 \mathrm{Ma}$ (after Grunau et al., 1975). This has not yet been well documented, however. Tentative correlations could eventually be made with volcanic Pleistocene phases ( $2-0.2 \mathrm{Ma})$, noted by AbdelMonem et al. $(1971,1972)$ in the Canary Islands.

Between these two major volcanic deposit episodes, the only volcanic supplies by turbidity currents occur in Section 108-659B-8H-2, 131-136 cm (late Pliocene, $\sim 2.2 \mathrm{Ma}$ ). The sequence base is underlain by an iron-oxide-rich crust, a few millimeters thick, and overlain by silty material composed of major quartz and minor volcanic grains (Plate 3 and Fig. 5). But the proportions of volcanic material are very low and do not provide a significant record of a high volcanic activity episode. Nevertheless, at Site 367, Sarnthein (1978) has found fresh volcanic elements (pumice) in sediments of the same age (2 Ma).

Quartz-rich turbidite sequences are more frequent than volcaniclastic turbidite sequences. But, compared with deposits at Site 657 (Faugères et al., this vol.), their frequency is very low. They are absent during the late Oligocene and very rare (about 3-4 sequences) during the Miocene. It means that during these periods, the Cape Verde Plateau was high enough to prevent strong turbiditic supply and, consequently, the uplift of the rise must have taken place before; this observation is not concordant with the uplift age (= $10 \mathrm{Ma}$ ) proposed by Lancelot and Seibold (1978). During the early Pliocene, the frequency is higher $(4$ sequences $/ 2$ m.y.), and it decreases again in the late Pliocene (only 2 sequences $/ 2$ m.y.). Siliciclastic turbidites are absent during Pleistocene time. 
Table 3. Comparison of turbidite, contourite, and pelagite characteristics (J. C. Faugères, M. Cremer, and E. Gonthier, pers. comm.).

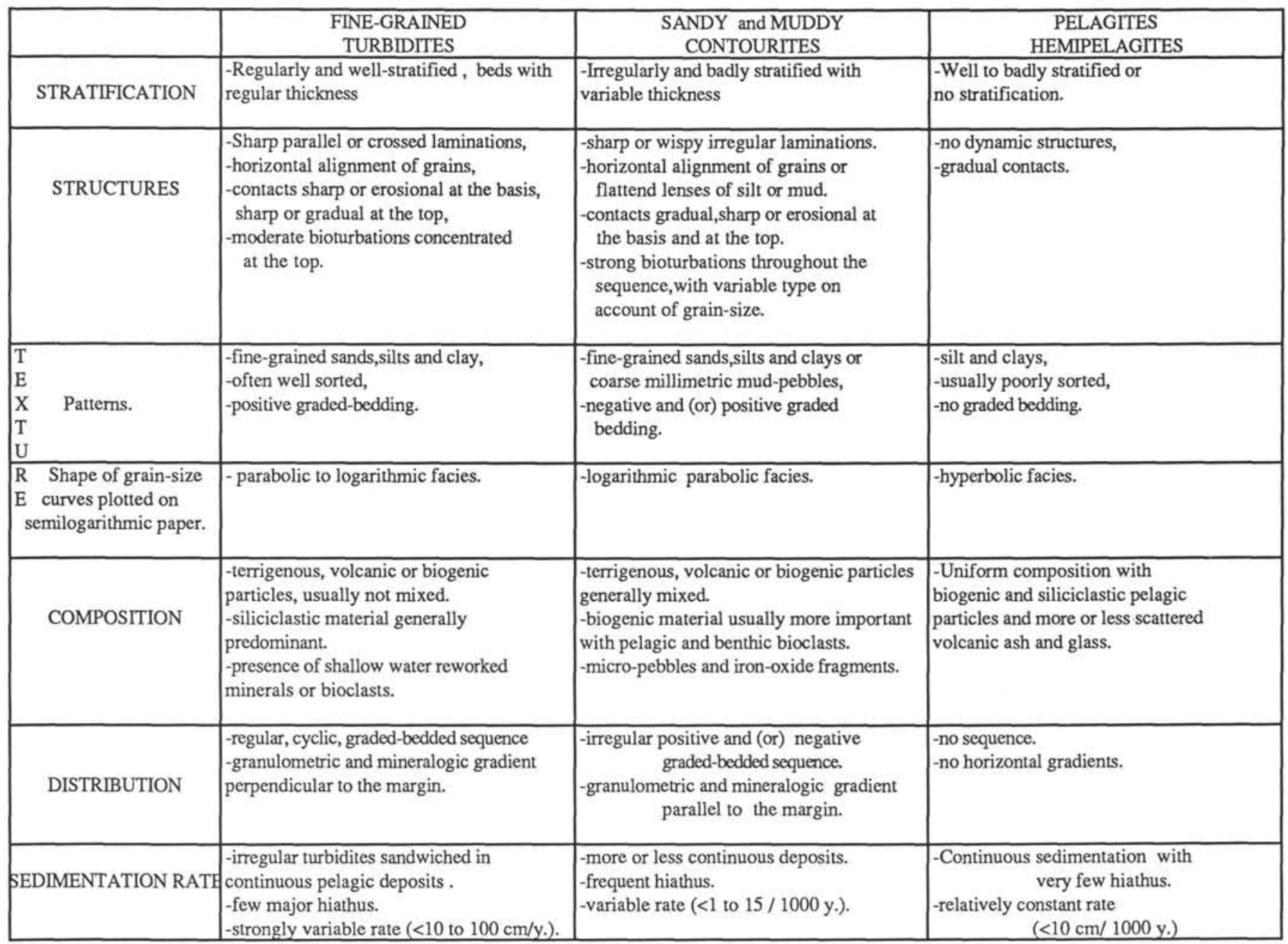

This vertical distribution shows that the strongest and most frequent turbidity currents took place during the early Pliocene, and terrigenous inputs were probably the most abundant at that time. Nearby Site 657 sediments also documented a high-turbidite frequency at that epoch ( 15 sequences/ $\sim 2$ m.y.) and confirm abundant continental supplies on the overall margin. The still higher frequency observed at Site 657 during the uppermost Pliocene and early Pleistocene (Faugères et al., this vol.) has not been recorded at Site 659.

According to their sandy-silty components, turbidite sequences seem rather uniform. Conversely, clay minerals show significant variations throughout the Neogene. So, we could use them as indicators of climate and sediment sources on the adjacent continent. Referring to previous works on clay mineral records of climate- and sediment-source variations (in Sarnthein et al., 1982, and Faugères et al., this vol.), we could tentatively propose an interpretation of clay mineral assemblage evolution.

Smectite is always present with noticeable proportions $(25 \%-35 \%)$ and in a few samples with high proportions $(40 \%-$ $50 \%$; assemblage 3 , Table 3 ). It must be considered as a ubiquitous mineral; it may be the result of direct continental supplies or of reworked marine deposits enriched in smectite by marine processes (Sarnthein and Koopman, 1980). Nevertheless, we have already noted that its proportions are gener- ally higher in turbidite basal term, especially in volcanic turbidites. More clear variations characterize kaolinite, illite, and chlorite proportions.

Hence, two periods can be distinguished. From the late Miocene to the beginning of the late Pliocene (from Sections 108-659A-20H-5, 83-89 cm, up to $108-659$ A-10H-2, 86-92 cm; Table 2), the sediments show very high $(60 \%$; assemblage 1 , Table 2) or high kaolinite contents (mean percentage: $40 \%$; assemblage 2 , Table 2 ) with smectite (30\%), lower illite $(20 \%)$, and very low chlorite $(10 \%)$ contents. From the latest Pliocene to the Holocene, clay assemblages show irregular variations but with an illite mean percentage $(25 \%-30 \%)$ generally higher than in the underlying sediments, and smectite proportions $(30 \%)$ more often higher than kaolinite $(25 \%)$, and very low chlorite $(5 \%-10 \%)$, except in a few samples (up to $14 \%$; assemblage $4, \mathrm{~S}+\mathrm{I}+\mathrm{K}$, and the exceptional assemblage 5 with $17 \%$ attapulgite, Table 2 ).

The first period might indicate predominant south Saharan sources and probably more humid conditions, especially during late Miocene time when kaolinite is very abundant. The second period is characterized by more fluctuating conditions but with a stronger influence of north Saharan continental sources and more arid general conditions. The boundary of the two periods should be about 2.6 Ma, which corresponds to the decrease of turbidite frequency during the late Pliocene. At Site 657 , a similar clay 


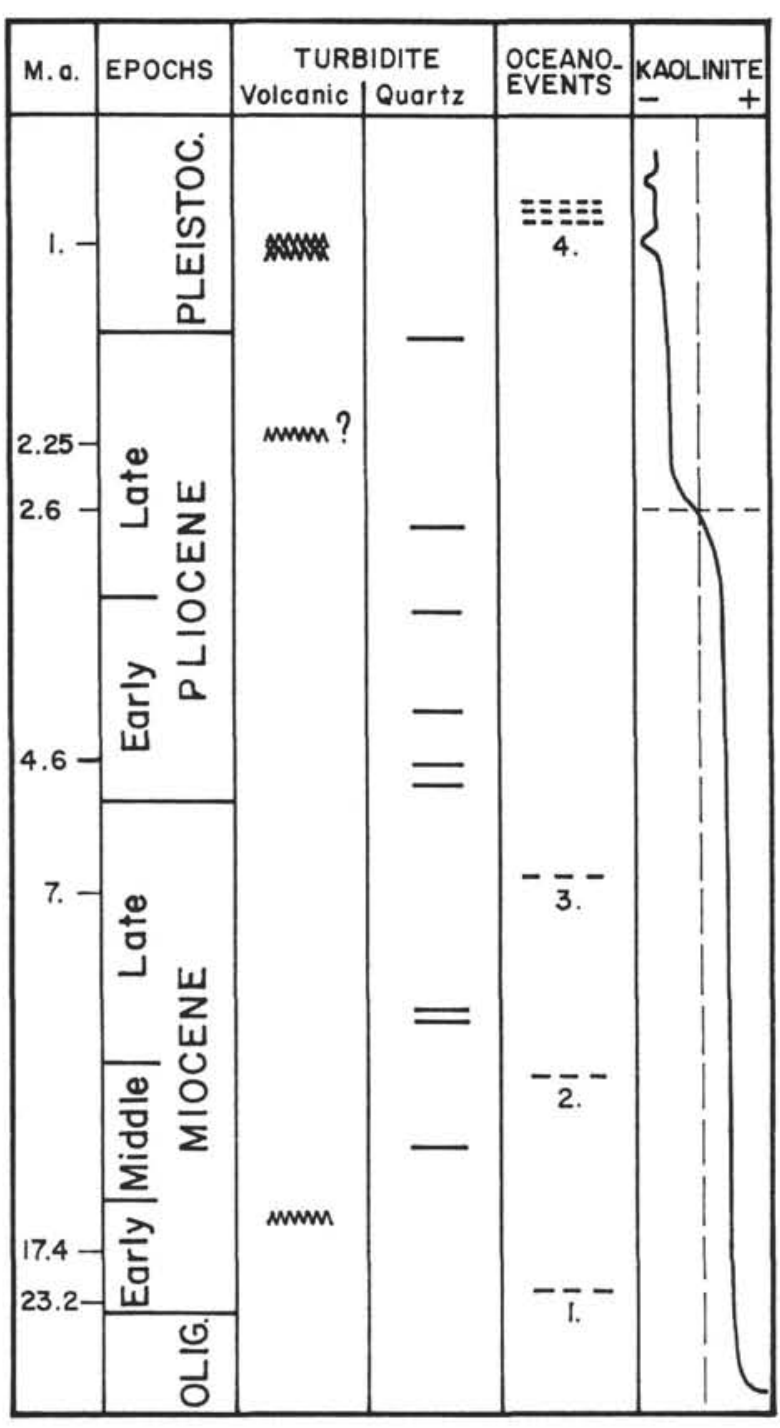

Figure 7. Schematic diagram of Site 659 showing results concerning the quartz-rich siliciclastic turbidite frequency, two volcaniclastic turbidite episodes, the bottom circulation variations, and a major clay mineral change at $\sim 2.6 \mathrm{Ma}$. Numbers $1,2,3$, and 4 refer to the three Miocene oceanographic events recorded at $\sim 18.5-23.5,11$, and 4.6 $\mathrm{Ma}$ and to the assumed increase of bottom currents during the Pleistocene, respectively.

assemblage change has been observed occurring approximately at the same time (2.9 Ma; Faugères et al., this vol.); it confirms a striking event in climatic conditions and continental sediment sources at $\sim 2.6-2.9 \mathrm{Ma}$. This change could be correlated with the strong modifications observed in the sedimentation regime, such as the higher amplitude of the carbonate cycle, the intensification of coastal upwelling documented by increases in the content of diatoms and organic carbon, and deposits increasingly rich in terrigenous silt and clay (Leg 108 Scientific Party, 1986).

\section{CONCLUSION}

At Site 659 located on the Cape Verde Plateau, pelagic cyclic sedimentation is largely predominant during the Neogene. The sediments are, however, slightly disturbed by a few thin turbiditic or contouritic layers, scattered irregularly throughout the section (Fig. 7).

Turbidite sequences account for less than $1 \%$ or $2 \%$ of Neogene deposits. They are fine grained and thin bedded with only C-D-E divisions of the Bouma sequence. The C and D divisions are always very thin (a few centimeters to $15 \mathrm{~cm}$ thick) and are composed of sandy-clayey silt or silty clay. This material is more often quartzitic, exceptionally volcanic, and, in two cases, mixed with calcareous pelagic tests. Quartz-rich sediments are supposedly supplied by the adjacent Senegalese continent and volcanic particles by the very close Cape Verde Islands.

The vertical distribution of turbidites led us to the following conclusions:

1. Very few turbidites (about 12 sequences) have reached the top of the Cape Verde Plateau in the last $25 \mathrm{~m} . \mathrm{y}$.; consequently, the uplift of the rise must have taken place earlier.

2. Quartz-rich turbidites are absent during the late Oligocene and their frequency is very low during the Miocene, a little higher during the early Pliocene, and again very low during the late Pliocene. They are absent during the Pleistocene. Therefore, we assume that turbidity currents were strongest and most frequent during the early Pliocene, and quartz-rich siliciclastic continental supplies were probably most abundant on the Senegalese margin.

3. Two episodes of volcaniclastic turbidites occurred in the early Miocene $(\sim 17 \mathrm{Ma})$ and early Pleistocene $(\sim 1 \mathrm{Ma})$ and may be related to a high degree of volcanic activity on the Cape Verde Islands.

Contourite sequences, more difficult to investigate, seem to account for less than $5 \%$ of Neogene deposits; they are composed of biogenic sandy-silty contourites. Compared with pelagic climatic sequences, they show different structural, textural, and component features with, in particular, an increase of foraminifer contents with respect to clay and nannofossils because of bottom current winnowing and reworking. Except for the three Miocene episodes during which bottom circulations vary strongly and drive a major hiatus or changes in the sedimentation regime, bottom currents seem to have been rather regular and slow with only slight variations and probably a minor increase at the end of the Pleistocene.

Clay mineral studies concerning the different sequences throughout Neogene deposits show predominant kaolinite before $\sim 2.6 \mathrm{Ma}$ and an increase trend of illite after. This change might be correlated with a decrease in turbidite frequency at Site 659 , a similar modification of clay mineral assemblages at Site 657 (Faugères et al., this vol.), and numerous other oceanographic modifications recorded in deposits of the overall northwest African margin (Leg 108 Scientific Party, 1986). They must correspond to a global paleogeographic and climatic event.

\section{REFERENCES}

Abdel-Monem, A., Watkins, N. D., and Gast, P. W., 1971. Potassium-argon ages, volcanic stratigraphy and geomagnetic polarity history of the Canary Islands Lanzarote, Fuerteventura, Gran Canaria and La Gomera. Am. J. Sci., 271:490-521.

1972. Potassium-argon ages, volcanic stratigraphy and geomagnetic polarity history of the Canary Islands: Tenerife, $\mathrm{La}$ Palmas and Hierro. Am. J. Sci., 272:805-825.

Bouma, A. H., 1962. Sedimentology of Some Flysch Deposits: Amsterdam (Elsevier).

1975. Turbidites, contourites and debrites in the Gulf of Mexico and the Colombian basin. IX $X^{\circ}$ I.A.S. Internat. Congr. (Nice, France). Theme 5, 1:83-91. 
Coumes, F., and Caratini, C., 1979. Etude et interprétation des profils d'échogrammes relevés a l'échosondeur C.S.F. (3.5 kHz). In Arnould, M., and Pelet, R. (Eds.), La Géochemie Organique des Sédiments Marins Profonds: Orgon III (Mauritanie, Sénégal, Iles du Cap Vert): Paris (CNRS), 883-892.

Dean, W. E., Gardner, J. V., Jansa, L. F., Čepek, P., and Seibold, E., 1978. Cyclic sedimentation along the continental margin of northwest Africa. In Lancelot, Y., Seibold, E., et al., Init. Repts. DSDP, 41: Washington (U.S. Govt. Printing Office), 965-989.

Diester-Haass, L., 1975. Late Quaternary sedimentation and climate in the East Atlantic between Senegal and Cap Verde Islands. Meteor Forschungsergeb., Reihe C, 20:1-32.

1978. Influence of carbonate dissolution, climate, sea-level changes and volcanism on Neogene sediments off northwest Africa. In Lancelot, Y., Seibold, E., et al., Init. Repts. DSDP, 41: Washington (U.S. Govt. Printing Office), 1033-1047.

Dietz, R. S., Knebel, H. J., and Sommers, L. H., 1968. Cayar submarine canyon. Geol. Soc. Am. Bull., 79:1821-1828.

Dillon, W. P., and Sougy, J.M.A., 1974. Geology of West Africa and Canary and Cape Verde Islands. In Nairn, A.E.M., and Stehli, F. G. (Eds.), The Ocean Basins and Margins: New York (Plenum Press), 2:315-390.

Duncan, R. A., and Jackson, E. D., 1978. Geochronology of basaltic rocks recovered by DSDP Leg 41, eastern Atlantic Ocean. In Lancelot, Y., Seibold, E., et al., Init. Repts. DSDP, 41: Washington (U.S. Govt. Printing Office), 1113-1118.

Faugères, J. C., Gonthier, E., and Stow, D., 1984. Contourite drift molded by deep Mediterranean outflow. Geology, 12:296-300.

Fritz, S. J., and Pilkey, O. H., 1975. Distinguishing bottom and turbidity current coarse layers on the continental rise. J. Sediment. Petrol., 45:57-62.

Gardner, J. V., Dean, W. E., and Jansa, L., 1977. Sediments recovered from the northwest African continental margin, Leg 41, Deep Sea Drilling Project. In Lancelot, Y., Seibold, E., et al., Init. Repts. DSDP, 41: Washington (U.S. Govt. Printing Office), 11211134.

Gonthier, E., Faugères, J. C., and Stow, D., 1984. Contourite facies of the Faro Drift, Gulf of Cadix. Geol. Soc. Spec. Publ. (London), 15:275-292.

Grunau, H. R., Lehner, P., Cleintuar, M. R., Allenbach, P., and Bakker, G., 1975. New radiometric ages and seismic data from Fuerteventura (Canary Islands), Maio (Cape Verde Islands) and Sao Tome (Gulf of Guinea): progress in geodynamics. $R$. Neth. Acad. Arts Sci., 90-118.

Hobart, M. A., Bunce, E. T., and Sclater, J. G., 1975. Bottom water flow through the Kane Gap, Sierra Leone Rise, Atlantic Ocean. J. Geophys. Res., 80:5083-5088.

Jacobi, R. D., 1976. Sediment slides on the northwestern continental margin of Africa. Mar. Geol., 22:157-173.

Jacobi, R., and Hayes, D., 1982. Bathymetry, microphysiography and reflectivity characteristics of the West African margin, between Sierra Leone and Mauritania. In von Rad, U., Hinz, K., Sarnthein, M., and Seibold, E. (Eds.), Geology of the Northwest African Continental Margin: Berlin-Heidelberg-New York (Springer-Verlag), 182-212.

Kennett, J., 1982. Marine Gerlogy: New York (Prentice Hall).

Lancelot, Y., and Seibold, E., 1978. The evolution of the central northeastern Atlantic: summary of results of DSDP Leg 41. In Lancelot, Y., Seibold, E., et al., Init. Repts. DSDP, 41: Washington (U.S. Govt. Printing Office), 1215-1245.

Leg 108 Scientific Party, 1986. Paleoclimate studied in the east Atlantic. Geotimes, 86:21-25.

Lonsdale, P., 1982. Sediment drifts of the Northeast Atlantic and their relationship to the observed abyssal currents. Bull. Inst. Geol. Bassin Aquitaine, 31-32:141-150.
Meinert, J., 1986. Akustostratigraphie im üquatorialen Ost-atlantik: Zur Entwicklung der Tiefenwasserzirkulation der letzten 3.5 Millionen Jahre. Meteor Forschungsergeb., Reihe C, 40:19-86.

Michell-Thomè, R. C., 1972. Outline of the geology of the Cape Verde Archipelago. Geol. Rundsch., 61:1087-1109.

Moyes, J., Duplantier, F., Duprat, J., Faugères, J. C., Pujol, C., Pujos-Lamy, A., and Tastet, J. P., 1979. Etude stratigraphique et sédimentologique. In Arnould, M., and Pelet, R. (Eds.), La Géochimie Organique des Sédiments Marins Profonds: Orgon III (Mauritanie, Sénégal, Iles du Cap Vert): Paris (CNRS), 121-213.

Nelson, H., Mutti, E., and Ricci Lucchi, F., 1975. Comparison of proximal and distal thin-bedded turbidites with current-winnowed deep sea sands. $I X^{\circ}$ I.A.S. Internat. Congr. (Nice, France). Theme $5,2: 317-323$.

Rivière, A., 1977. Méthodes Granulométriques: Techniques et Interprétation: Paris (Masson).

Rothe, P., and Koch, R., 1978. Miocene volcanic glass from DSDP Sites 368, 369, and 370. In Lancelot, Y., Seibold, E., et al., Init. Repts. DSDP, 41: Washington (U.S. Govt. Printing Office), 10611064.

Ruddiman, W., Sarnthein, M., et al., 1988. Proc. ODP, Init. Repts., 108: College Station, TX (Ocean Drilling Program).

Sarnthein, M., 1978. Neogene sand layers off northwest Africa: composition and source environment. In Lancelot, Y., Seibold, E., et al., Init. Repts. DSDP, Suppl. 38, 39, 40, and 41: Washington (U.S. Govt. Printing Office), 939-959.

Sarnthein, M., and Koopmann, B., 1980. Late Quaternary deep-sea record on NW African dust supply and wind circulation. Palaeoecol. Africa, 12:239-253.

Sarnthein, M., Theide, J., Pflaumann, U., Erlenkeuser, H., Fütterer, D., Koopmann, B., Lange, H., and Seibold, E., 1982. Atmospheric and oceanic circulation patterns off northwest Africa during the past 25 million years. In von Rad, U., Hinz, K., Sarnthein, M., and Seibold, E. (Eds.), Geology of the Northwest African Continental Margin: Berlin-Heidelberg-New York (Springer-Verlag), 545-603.

Sarnthein, M., and Mienert, J., 1986. Sediment waves in the eastern equatorial Atlantic: sediment record during late glacial and interglacial times. In Summerhayes, C. P., and Shackleton, N. J. (Eds.), North Atlantic Paleoceanography. Geol. Soc. Spec. Publ. (London), 21:119-130.

Shipboard Scientific Party, 1978a. Site 367: Cape Verde Basin. In Lancelot, Y., Seibold, E., et al., Init. Repts. DSDP, 41: Washington (U.S. Govt. Printing Office), 163-232.

Shipboard Scientific Party, 1978b. Site 368: Cape Verde Rise. In Lancelot, Y., Seibold, E., et al., Init. Repts. DSDP, 41: Washington (U.S. Govt. Printing Office), 233-254.

Shipboard Scientific Party, 1978c. Site 369: Continental slope off Cape Bajadoz, Spanish Sahara. In Lancelot, Y., Seibold, E., et al., Init. Repts. DSDP, 41: Washington (U.S. Govt. Printing Office), $327-$ 420 .

Stow, D., 1982. Bottom currents and contourites in the North Atlantic. Bull. Inst. Geol. Bassin Aquitaine, 31:151-166.

Stow, D., and Piper, D., 1984. Fine-grained sediments: deep-water processes and facies. Geol. Soc. Spec. Publ. (London), 15.

Uchuppi, E., Emery, K. O., Bowin, C. O., and Philipps, J. D., 1976. Continental margin off western Africa: Senegal to Portugal. $A A P G$ Bull., 60:809-878.

Date of initial receipt: 10 May 1988

Date of acceptance: 1 December 1988

Ms 108B-138 


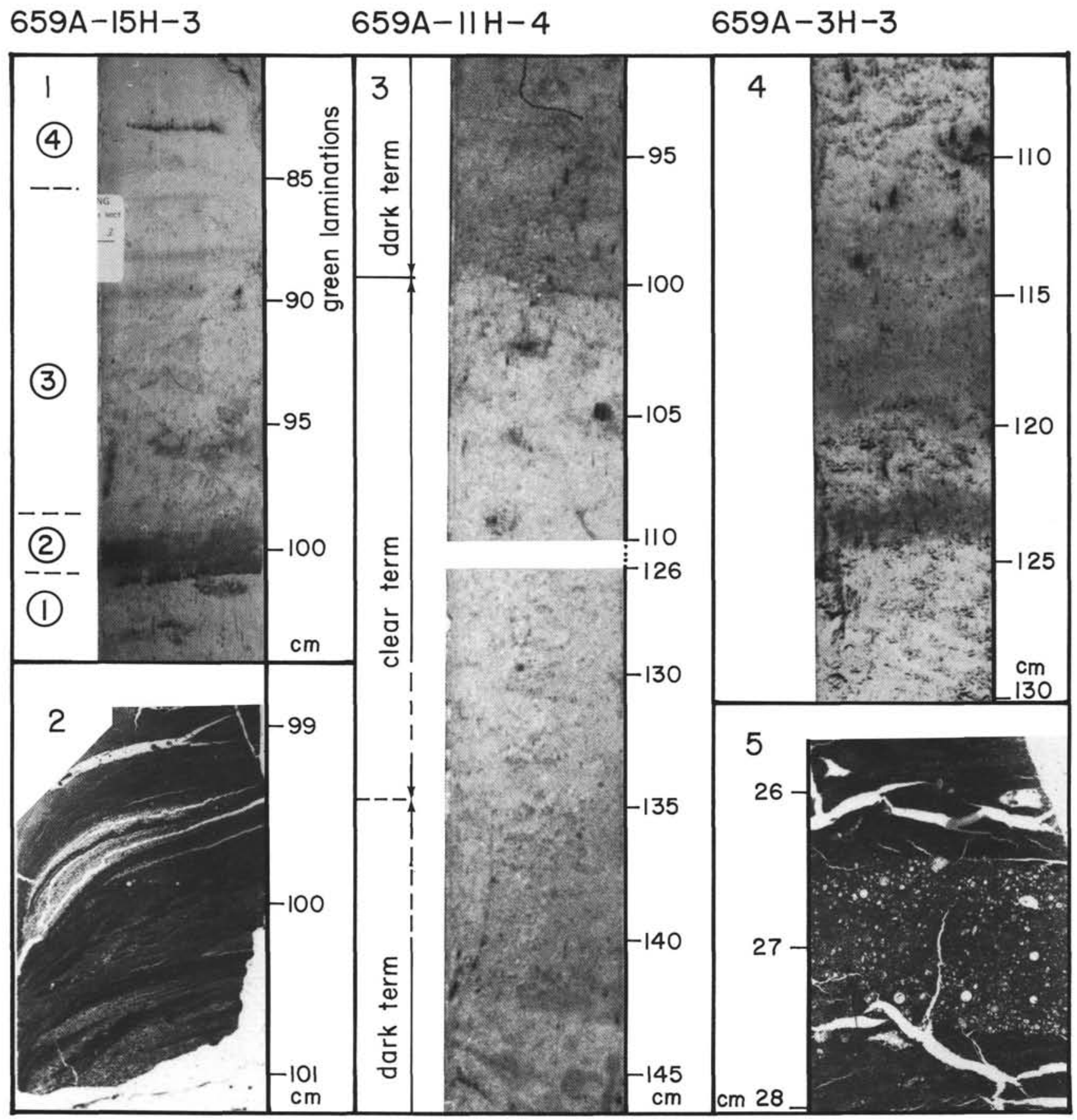

Plate 1. Different sequence types. 1. Turbidite sequence (Section 108-659A-15H-3). 2. Microfacies of the basal term (thin section of indurated sediment slide). 3. Climatic sequence (Section 108-659A-11H-4). 4. Contourite sequence (Section 108-659A-3H-3). 5. Detail of a coarse-grained, foraminifer-rich layer interbedded in fine-grained nannofossil ooze and showing sharp contacts between the two deposits. 


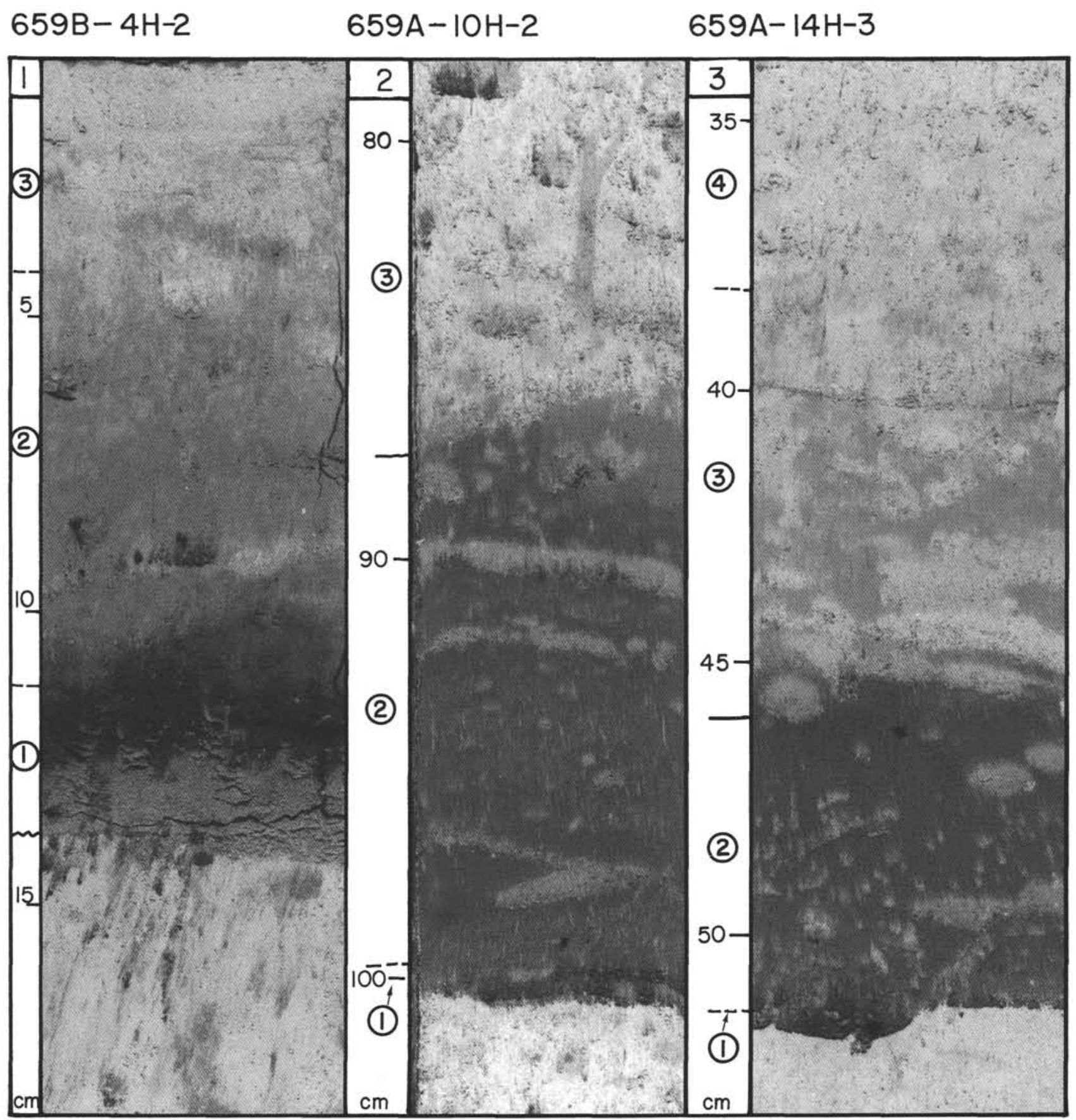

Plate 2. Turbidite sequences (dark sandy-silty layers). 1. Section 108-659B-4H-2. 2. Section 108-659A-10H-2. 3. Section 108$659 \mathrm{~A}-14 \mathrm{H}-3$. Numbers $1,2,3$, and 4 in circles $=$ different terms of the sequences. 


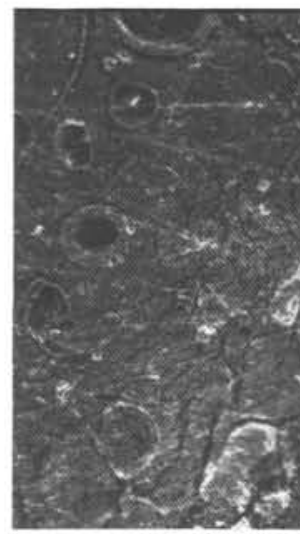

1

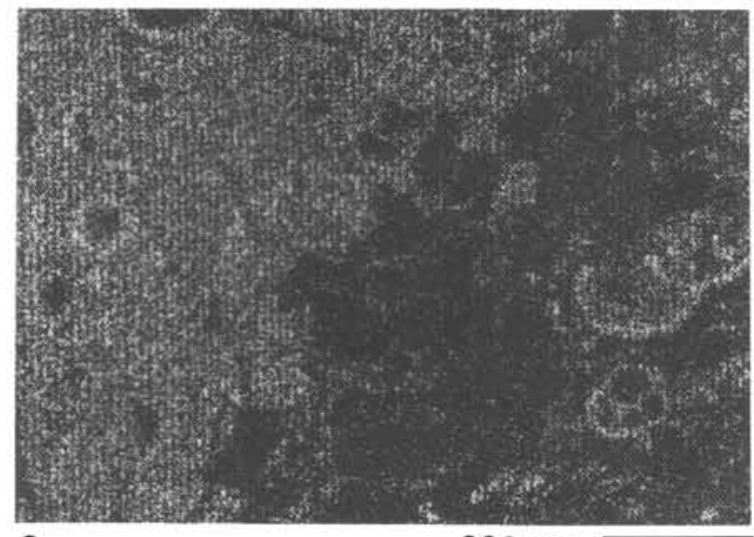

3

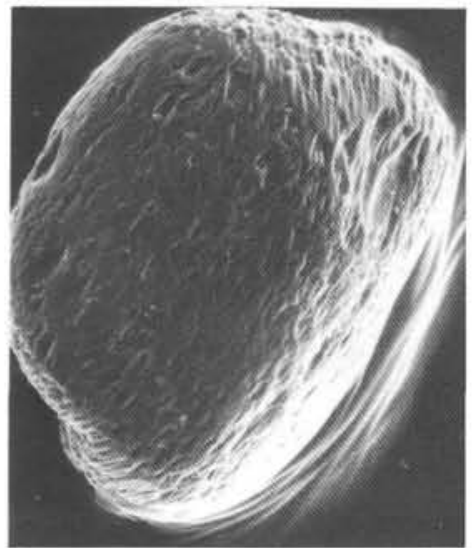

$5200 \mu \mathrm{m}$
$200 \mu \mathrm{m}$

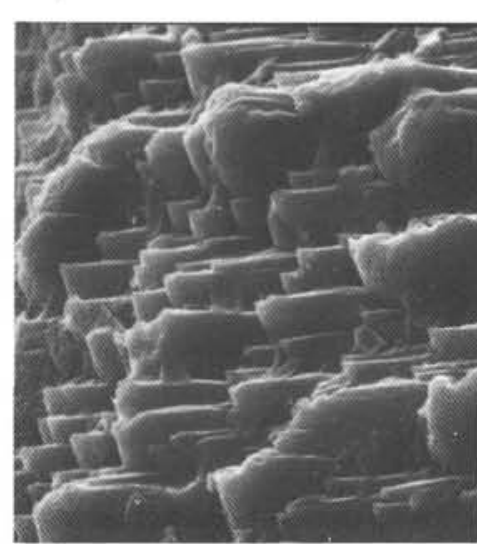

$20 \mu \mathrm{m}$

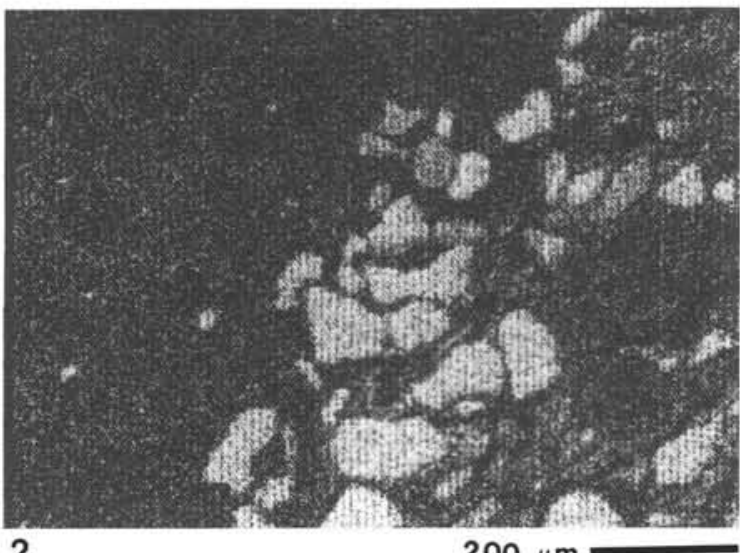

2

$200 \mu \mathrm{m}$

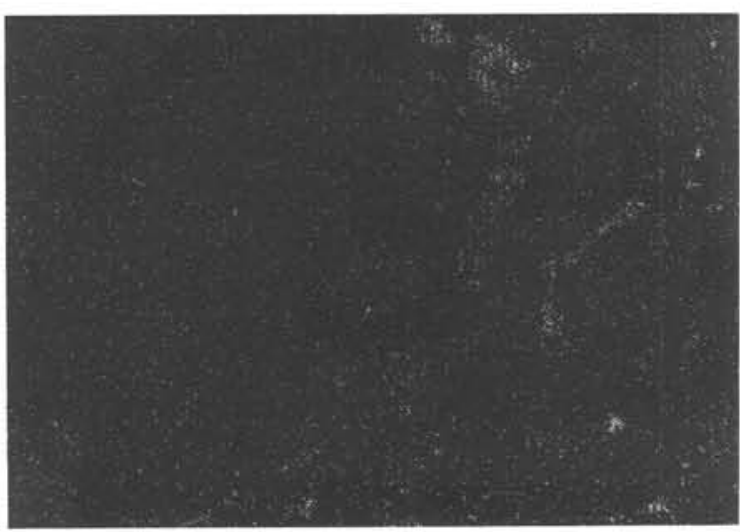

4

$200 \mu \mathrm{m}$

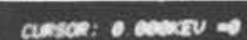

\&

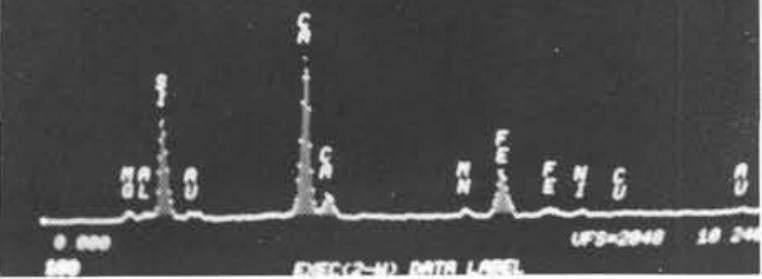

Plate 3. Component assemblage in basal turbidite sediments (Sample 108-659A-14H-3, $52 \mathrm{~cm}$ ): analysis of an indurated polished sediment slide by scanning electron microscope, coupled with dispersive energy spectrometer and other detectors (X-rays, backscattering electron). 1. Contact between the coarse-grained term 1 of the sequence and the underlying pelagic ooze. 2. Silicon distribution in (1) showing the predominant quartz grains at the basis of the sequence. 3. Carbonate distribution in (1) showing that this material is mixed with biogenic calcareous particles. 4. Iron distribution in (1). 5. Evidences of volcanic material in Sample 108-659B-8H-2, 136 cm. A well-rounded pyroxene grain, its typical cleavages, and its global chemical composition are shown from left to right. 


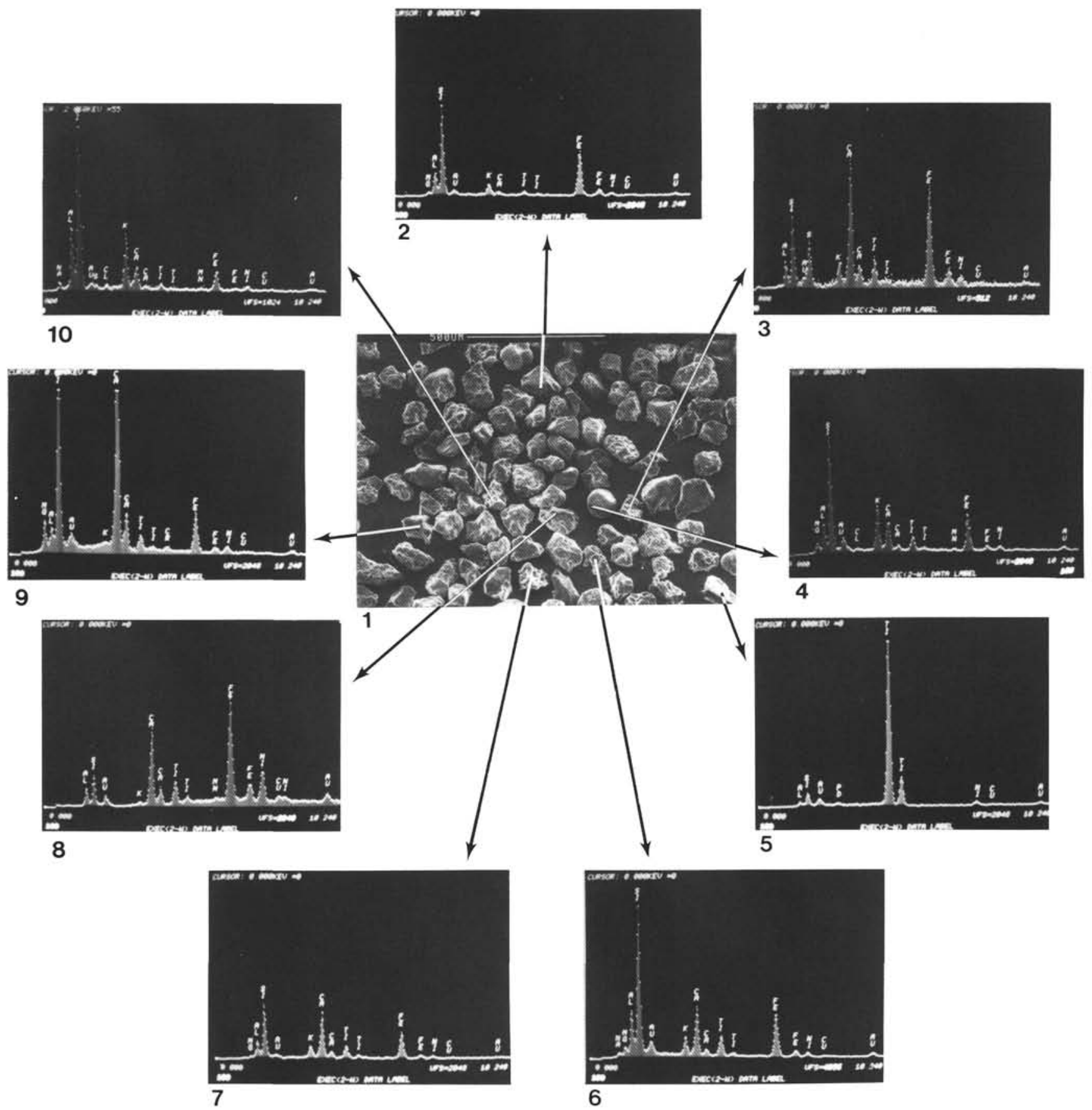

Plate 4. Volcanic components of a turbidite from Sample 108-659B-4H-2, 11-13 cm. 1. Different aspects of detrital grains. 2. Massive brownish amphibole. 3. Volcanic ash (aggregated minerals with zeolites?). 4. Well-rounded amphibolite grain (greenish hornblende). 5. Reddish rutile. 6. Fresh grain of brownish basaltic hornblende. 7. Volcanic glass. 8. Pyroxene(?). 9. Light yellow pyroxene. 10. Grain with aggregated hornblende. 

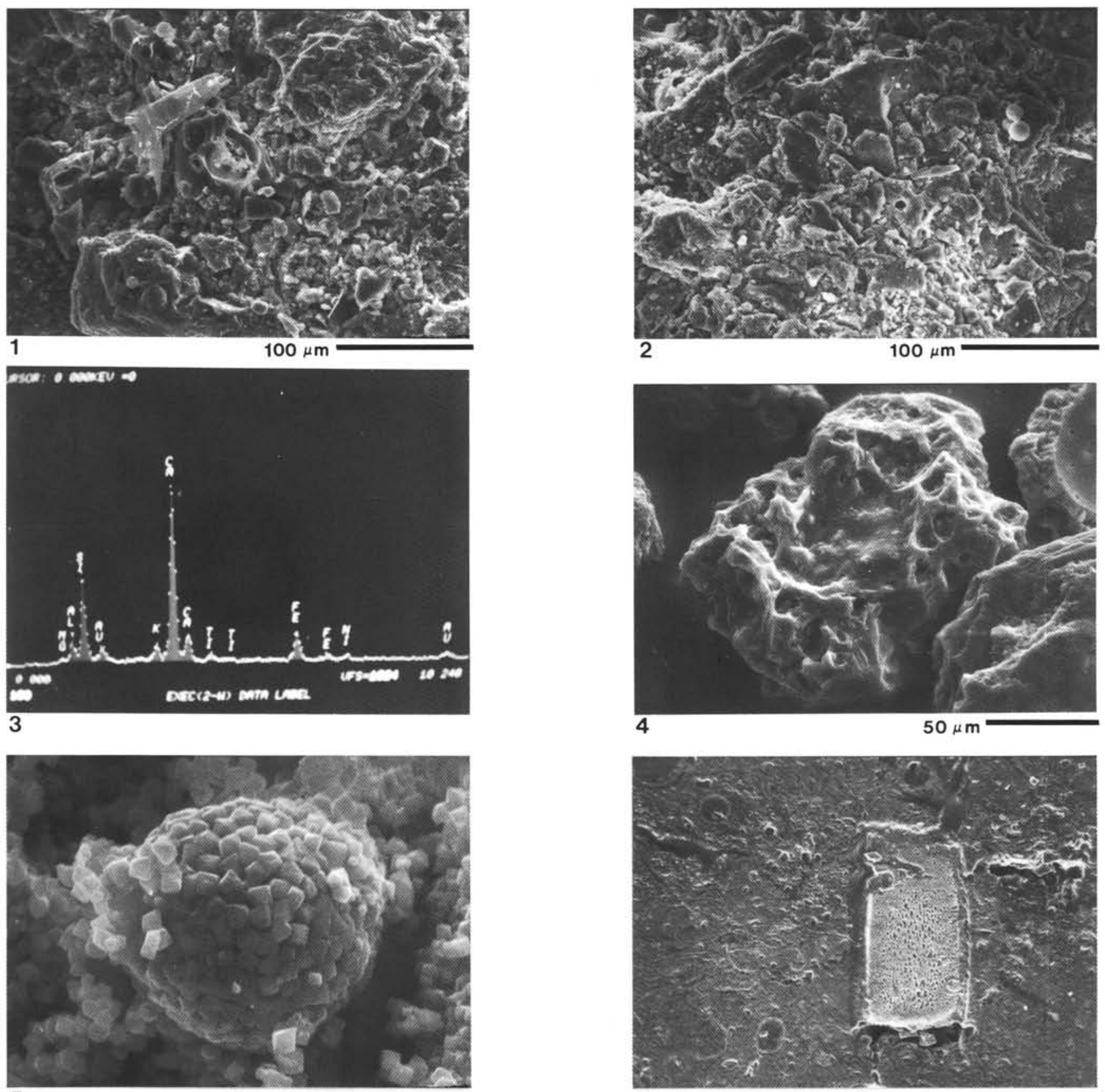

5

$10 \mu \mathrm{m}$

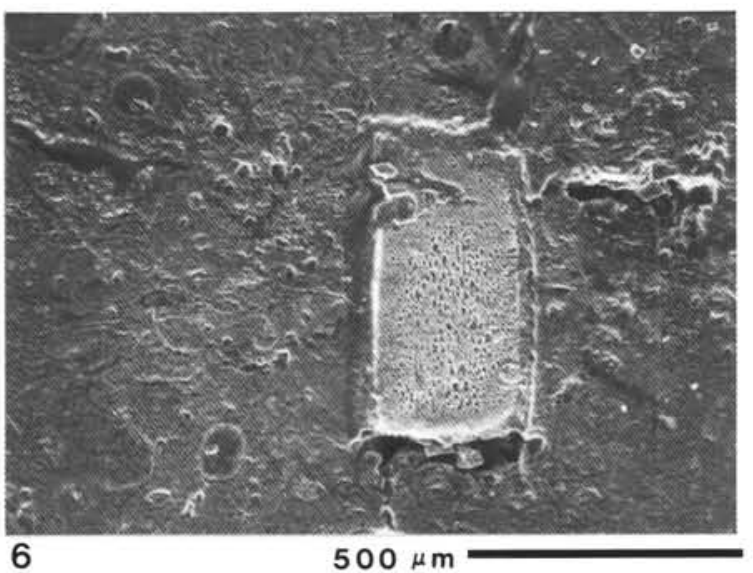

Plate 5. Volcanic particles from Sample 108-659B-4H-2, 11-12 cm. Ash grains (1 and 2) with same global composition (3) and fresh glass grain (4). 5. Framboidal pyrite. 6. Detritic gypsum grain. 